\title{
Identification of mitogen-activated protein kinase docking sites in enzymes that metabolize phosphatidylinositols and inositol phosphates
}

\author{
Kevin K Caldwell*, Marcos Sosa and Colin T Buckley
}

Address: Department of Neurosciences University of New Mexico Health Sciences Center Albuquerque, NM 87131 USA

Email: Kevin K Caldwell* - KCaldwell@salud.unm.edu; Marcos Sosa - MSosa@salud.unm.edu; Colin T Buckley - CBuckley@salud.unm.edu

* Corresponding author

Published: 30 january 2006

Cell Communication and Signaling 2006, 4:2 doi:10.1186/1478-8IIX-4-2

This article is available from: http://www.biosignaling.com/content/4/I/2

(C) 2006 Caldwell et al; licensee BioMed Central Ltd.

This is an Open Access article distributed under the terms of the Creative Commons Attribution License (http://creativecommons.org/licenses/by/2.0), which permits unrestricted use, distribution, and reproduction in any medium, provided the original work is properly cited.
Received: 0 I November 2005 Accepted: 30 january 2006

\begin{abstract}
Background: Reversible interactions between the components of cellular signaling pathways allow for the formation and dissociation of multimolecular complexes with spatial and temporal resolution and, thus, are an important means of integrating multiple signals into a coordinated cellular response. Several mechanisms that underlie these interactions have been identified, including the recognition of specific docking sites, termed a D-domain and FXFP motif, on proteins that bind mitogen-activated protein kinases (MAPKs). We recently found that phosphatidylinositol-specific phospholipase C- $\gamma$ I (PLC- $\gamma \mathrm{I}$ ) directly binds to extracellular signal-regulated kinase 2 (ERK2), a MAPK, via a D-domain-dependent mechanism. In addition, we identified D-domain sequences in several other PLC isozymes. In the present studies we sought to determine whether MAPK docking sequences could be recognized in other enzymes that metabolize phosphatidylinositols (PIs), as well as in enzymes that metabolize inositol phosphates (IPs).

Results: We found that several, but not all, of these enzymes contain identifiable D-domain sequences. Further, we found a high degree of conservation of these sequences and their location in human and mouse proteins; notable exceptions were PI 3-kinase C2- $\gamma$, PI 4-kinase type II $\beta$, and inositol polyphosphate Iphosphatase.

Conclusion: The results indicate that there may be extensive crosstalk between MAPK signaling and signaling pathways that are regulated by cellular levels of PIs or IPs.
\end{abstract}

\section{Background}

MAPKs catalyze the transfer of the $\gamma$-phosphate of adenosine triphosphate (ATP) to serine (S) or threonine (T) residues that precede proline $(P)[1,2]$; thus, these enzymes are termed proline-directed serine/threonine kinases. Although the sequences ST and TP are sufficient for phosphorylation to occur, the optimal sequence for phosphorylation by a MAPK is $\operatorname{PX}(\mathrm{S} / \mathrm{T}) \mathrm{P}[1,3]$. The majority of cellular proteins contain an SP or a TP sequence, yet, many of these proteins are not MAPK substrates [4], indi- cating that a mechanism exists for achieving substrate specificity for the MAPKs. This specificity is conferred by the substrate through a docking domain. In addition to underlying specificity, these docking interactions increase the catalytic efficiency of substrate phosphorylation [5-7].

\section{MAPK docking sites}

A MAPK docking site, distinct from the phosphoacceptor site, was first identified in c-Jun [8,9], a c-Jun N-terminal kinase (JNK) substrate; this site was designated the " $\delta$ 
domain". Subsequently, a JNK binding site in the transcription factor ATF-2 $[10,11]$ and a motif termed the "dbox" of Elk-1 that binds ERK2 $[4,12]$ were noted to be similar in sequence to the JNK binding site in c-Jun. Related motifs have been identified in a number of other proteins and have been given various names, including DEJL (docking sites for ERK and JNK, LXL) domain [4], kinase interaction motif (KIM) [13,14], MAPK-docking site $[15,16]$, D box [5,12], D-site [17] and D-domain $[6,18-20]$. It is important to note that, although these domains were identified based on the ability to bind one or more MAPK, there are differences in the consensus sequences used to identify each of them. For example, MacKenzie et al. [14] proposed a consensus KIM sequence of $(\mathrm{V} / \mathrm{L}) \mathrm{X}_{2}(\mathrm{R} / \mathrm{K})(\mathrm{R} / \mathrm{K}) \mathrm{X}_{(3-6)} \mathrm{L}$, with $\mathrm{V}, \mathrm{L}, \mathrm{R}$, and $\mathrm{K}$ representing the amino acids valine, leucine, arginine and lysine, respectively; Bardwell et al. [16] define a consensus MAPK-binding site sequence of $(\mathrm{R} / \mathrm{K})_{2} \mathrm{X}_{(2-6)}(\mathrm{L} / \mathrm{I}) \mathrm{X}(\mathrm{L} / \mathrm{I})$, with I representing the amino acid isoleucine; and Kornfeld and colleagues [4] reported two consensus sequences for the DEJL domain: $(\mathrm{K} / \mathrm{R}) \mathrm{X}(\mathrm{X} / \mathrm{K} / \mathrm{R})(\mathrm{K} / \mathrm{R}) \mathrm{X}_{(1-4)}(\mathrm{L} / \mathrm{I}) \mathrm{X}(\mathrm{L} /$ I) and $(K / R)(K / R)(K / R) X_{(1-5)}(L / I) X(L / I)$. In the present studies we use the term $\mathrm{D}$-domain and the consensus sequences reported by Kornfeld and colleagues [4].

Sharrocks and colleagues [21] report that D-domains are characterized by a cluster of basic residues positioned amino-terminal to an (L/I)X(L/I) motif followed by a triplet of hydrophobic amino acids that precedes a series of proline residues $[17,21]$. These investigators assessed the role of each of these regions in the binding of ERK2 and p38 to transcription factors, MEF2A, SAP-1, and Elk-1. They determined that mutation of the basic region of the transcription factors reduced their phosphorylation by both phospho-ERK2 and phospho-p38 [21]. This suggests that the basic residues are important for both ERK2 and p38 targeting of MAPK substrates. Mutation of the (L/ I)X(L/I) motif (also called the LXL motif) diminished phosphorylation of phospho-ERK substrates, whereas it is not required for phosphorylation of substrates by the MAPK, phospho-p38 [21]. It was also determined that the hydrophobic patch plays an important role in phosphorylation of the substrates by both phospho-ERK and phospho-p38; however, this patch is more important for p38 binding than ERK2 binding. Barsyte-Lovejoy et al. [21] concluded that the proline residues were not important in specificity determination of MAPK substrates. Therefore, the authors hypothesize that the proline residues may play a structural role within the motif.

D-domains can show specificity for families of MAPKs; for example, the Elk-1 D-domain binds JNK and ERK, but not p38 [5,22]; both the SAP-1 and Elk-1 D-domains bind ERK2, whereas the SAP-1, but not Elk-1, D-domain binds p38 $\alpha$ [22]. Other D-domains show specificity within a
MAPK family; for example, the SAP-1 D-domain binds $\mathrm{p} 38 \alpha$ and $\mathrm{p} 38 \beta$, but not $\mathrm{p} 38 \delta$ [22]. The D-domain can be positioned either $\mathrm{N}$ - or C-terminal to the phosphorylation site $[7,12,16,19,23]$.

A second MAPK docking motif has also been identified: the FXFP motif, or DEF (docking site for ERK, FXFP) motif $[4,18,22]$, where $F$ and $P$ represent the amino acids phenylalanine and proline, respectively. Binding and substrate phosphorylation can occur in the absence of the proline residue $[14,18]$; however, its presence does increase the effectiveness of the motif [18]. Thus, we chose to include the proline in our searches. The identity of the second $(\mathrm{X})$ residue is highly variable $[4,18]$. In most, if not all, proteins, the FXFP motif is C-terminal to the phosphorylation site $[4,18,19,24]$. In general, it appears that the FXFP motif occurs more proximal to a phosphorylation site than is often the case for a D-domain $[4,18,20,22,24]$. The FXFP motif binds ERK2 and p38 $\alpha[18,22]$, but not JNK3 [4] and p38 $\beta[4,22]$. The FXFP motif and D-domain are each sufficient for MAPK docking; however, when both are present in a protein, they function additively $[18,22]$.

We recently identified a D-domain sequence in PLC- $\gamma 1$ and provided strong evidence that this sequence mediated an observed interaction between PLC- $\gamma 1$ and phosphoERK2 [25]. We have also reported that PLC- $\gamma 2,-\beta 1,-\beta 2$, and $-\beta 4$ each have at least one identifiable D-domain, as well co-immunoprecipitate with ERK2 [26]. Based on these observations, we have proposed that MAPK signaling and the metabolism of PIs are integrated. In order to substantiate this hypothesis, we sought to determine whether MAPK docking sites could be recognized in other enzymes that metabolize PIs; additionally, we sought support for extending this hypothesis to include the metabolism of IPs.

\section{Overview of phosphatidylinositol and inositol phosphate metabolism and signaling}

Eight PIs and more than 20 IPs have been identified [27$30]$. Several reviews of the metabolism and cellular roles of these molecules have appeared [27-35]. As the physiologic functions of the PIs and IPs were not a primary focus of the present studies, we will not summarize this information here; instead, the interested reader is directed to the sources cited above; we acknowledge that this is only a partial listing of the reviews that have been written on these subjects. PIs are substrates for a variety of phospholipases, acyl transferases, kinases and phosphatases, while IPs are metabolized by a series of kinases and phosphatases. Of these enzymes, we have limited the scope of the present studies to kinases and phosphatases. In order to assist the reader in understanding the reactions catalyzed by the enzymes which we analyzed, the pathways for the metabolism of PIs and IPs by various kinases and 
A

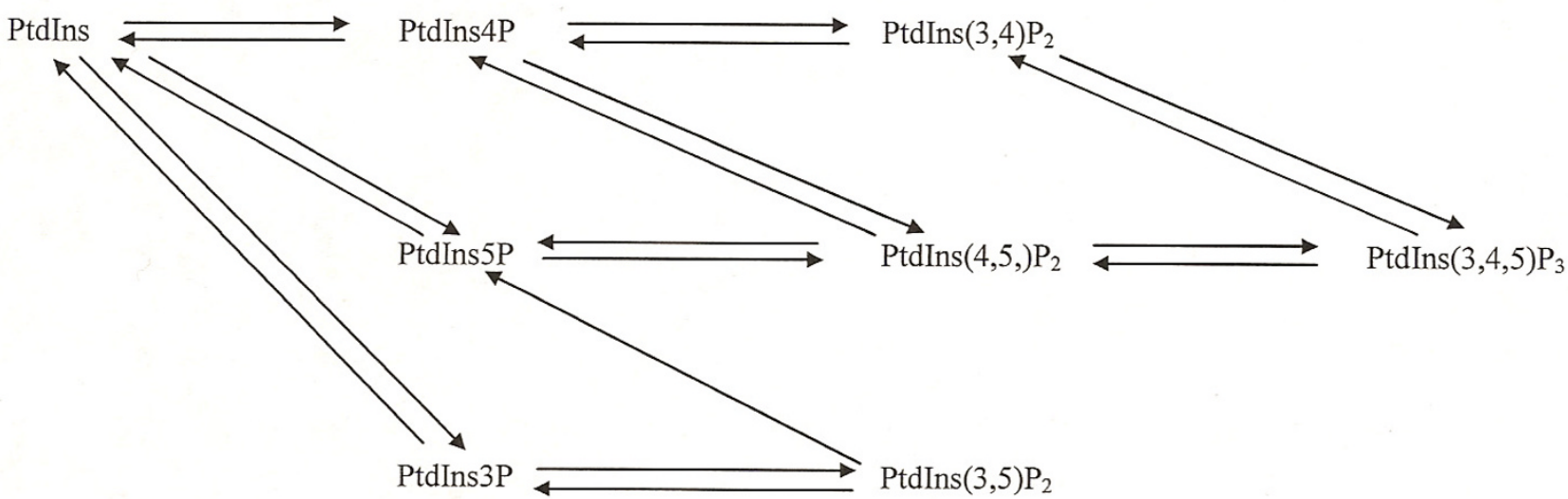

B

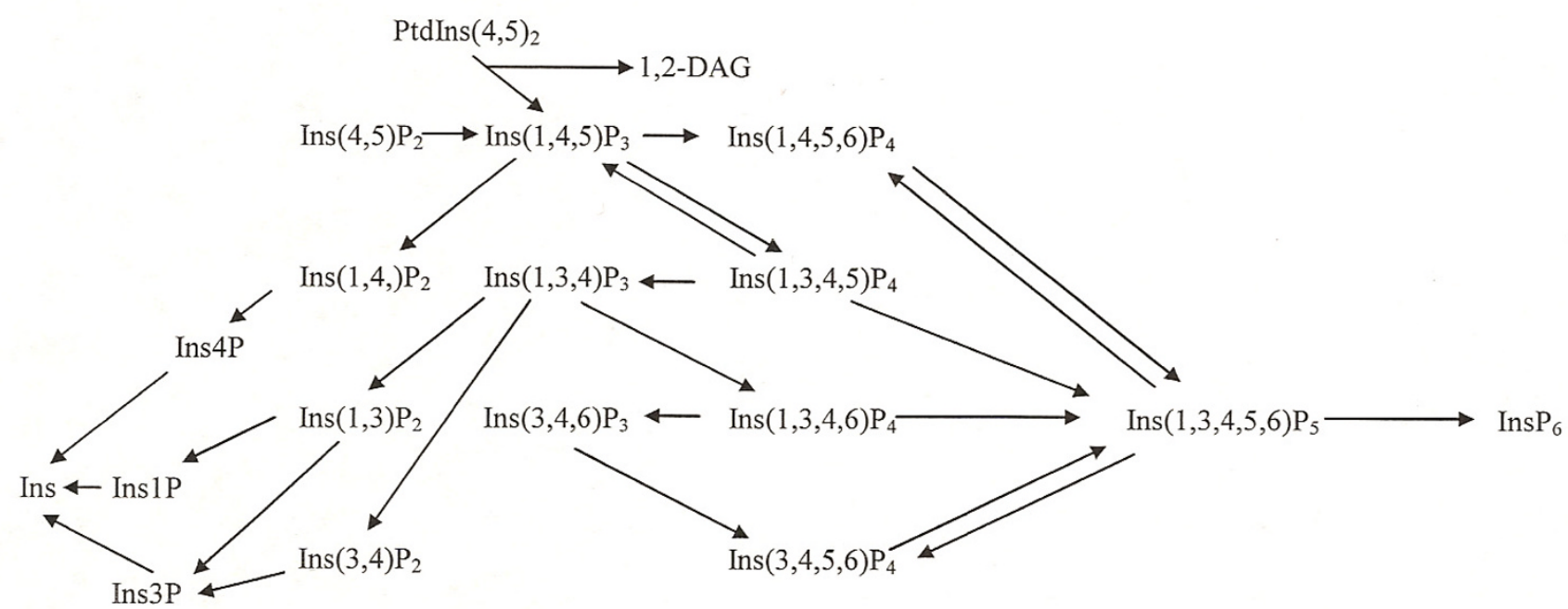

Figure I

A: Pathways of metabolism of phosphatidylinositols in animals. This figure is based on similar figures in Toker [28] and Parker [29] and information provided in the Results and Discussion section. We are not aware of evidence that Ptdlns5P is a substrate for a PI 3-kinase, producing Ptdlns $(3,5) \mathrm{P}_{2}$; therefore, an arrow has not been included for this reaction.

B: Pathways of inositol phosphate metabolism. The pathways of the metabolism of inositol phosphates in animal cells are shown; additional pathways are present in plants and slime mold [30]. The PLC-catalyzed synthesis of I,2-diacylglycerol (I,2-DAG) and Ins $(I, 4,5) \mathrm{P}_{3}$ is also shown. The figure is based on similar figures found in Irvine and Schell [30], Shears [36], and Irvine [37], as well as information provided in the Results and Discussion section.

phosphatases are shown in Figures $1 \mathrm{~A}$ and $1 \mathrm{~B}$, respectively. We use the IUPAC-IUB nomenclature for the identification of phosphatidylinositol (PtdIns) and inositol (Ins) phosphates (P): numbers are used to designate the carbon atoms to which phosphate groups are bound and the total number of phosphate groups is designated by a subscript, with the exception that no subscript is employed to designate the presence of a single phosphate group. For example, phosphatidylinositol 4-phosphate is designated PtdIns4P and inositol 1,4,5-trisphosphate is designated Ins $(1,4,5) \mathrm{P}_{3}$. For a review of inositol phosphate chemistry the reader is referred to recent articles by Shears [36] and Irvine [37].

\section{Results and discussion Search strategy}

We obtained the primary sequences of human and mouse kinases and phosphatases that control the phosphoryla- 
Table I: Kinases (human) that have an FXFP motif and/or D-domain sequence. The number of potential MAPK phosphorylation sites, sequences fitting the optimal MAPK phosphorylation consensus sequence of PX(S/T)P, and FXFP motifs and D-domain sequences in kinases that use phosphatidylinositols or inositols as substrates are listed in the table; all sequences are for human proteins.

\begin{tabular}{|c|c|c|c|c|c|c|}
\hline Tsozyme & $\begin{array}{c}\text { GenBank } \\
\text { Accession \# }\end{array}$ & $\begin{array}{l}\text { \# amino } \\
\text { acids }\end{array}$ & $\begin{array}{l}\text { number of }(\mathrm{S} / \\
\mathrm{T}) \mathrm{P} \text { sites }\end{array}$ & $\begin{array}{l}\text { Site(s) with the consensus } \\
\text { PX(S/T)P sequence }\end{array}$ & $\begin{array}{l}\text { FXFP } \\
\text { motif }\end{array}$ & D-domain motif \\
\hline \multicolumn{7}{|c|}{ PI 3-kinase } \\
\hline \multicolumn{7}{|l|}{ Class I } \\
\hline PI 3-kinase $\alpha$ & $\underline{\mathrm{P} 42336}$ & 1068 & 6 & none & none & $\begin{array}{l}{ }^{27 I} \mathrm{KYIRSCIML} \\
\text { 398RAARLCLSI }\end{array}$ \\
\hline $\begin{array}{l}\text { PI 3-kinase } \gamma \\
\text { PI 3-kinase } \delta\end{array}$ & $\frac{P 48736}{N P 005017}$ & $\begin{array}{l}1101 \\
1044\end{array}$ & $\begin{array}{c}13 \\
4\end{array}$ & $\begin{array}{l}\text { none } \\
\text { none }\end{array}$ & $\begin{array}{l}\text { none } \\
585 \text { FSFP }\end{array}$ & $\begin{array}{l}\text { 806KKKPLWL } \\
\text { none }\end{array}$ \\
\hline \multicolumn{7}{|l|}{ Class II } \\
\hline 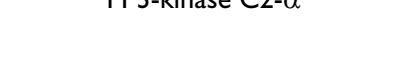 & $1 \mathrm{Nr} 002030$ & 1000 & 10 & $\begin{array}{l}\text { 199PLTP } \\
\text { 202PATP }\end{array}$ & none & 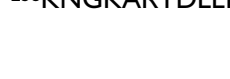 \\
\hline PI 3-kinase, C2- $\gamma$ & CAA03853 & 1448 & 9 & none & none & $\begin{array}{c}\text { 400KVSRQCLLTL } \\
\text { 830KEQKLIKI } \\
1327 \mathrm{KKPKVQLVI} \\
1347 \mathrm{KHMKNIHL}\end{array}$ \\
\hline \multicolumn{3}{|l|}{ Class III } & 6 & none & none & 656KLLRKENLDL \\
\hline \multicolumn{7}{|c|}{ PI 4-kinase } \\
\hline PI 4-kinase $\alpha$ (PI4K230) & $\underline{\mathrm{P} 42356}$ & 2044 & 16 & $\begin{array}{l}215 \text { PSSP } \\
\text { 590PPSP }\end{array}$ & $\begin{array}{l}\text { 1822FVF } \\
\mathrm{P}\end{array}$ & $\begin{array}{c}{ }_{15}^{15} \text { RRDAAVIAL } \\
\text { 15RRRDAVIALGI } \\
\text { 1340KRLREDISI } \\
\text { 1340KRLREDISIMI } \\
1429 \mathrm{KRRTLLL} \\
\text { 1429 KRRTLLLSL }\end{array}$ \\
\hline PI 4-kinase $\beta$ (PI4K92) & NP 002642 & 828 & 7 & none & none & $\begin{array}{c}\text { 244RGTKLRKLIL } \\
\text { 360KTQRLISELSL } \\
\text { 608 KPYKILVI }\end{array}$ \\
\hline $\begin{array}{l}\text { PI 4-kinase type II (PI4K55) } \\
\text { PI 4-kinase type II- } \beta \text { (PI4K55) }\end{array}$ & $\begin{array}{l}\text { NP } 060895 \\
\text { NP } 060793 \\
\end{array}$ & $\begin{array}{l}479 \\
481\end{array}$ & $\begin{array}{l}5 \\
3\end{array}$ & $\begin{array}{l}\text { 49PGSP } \\
\text { none }\end{array}$ & $\begin{array}{l}\text { none } \\
\text { none }\end{array}$ & $\begin{array}{l}\text { 435KDNKSPLHL } \\
239 \mathrm{KVGRKFHRIGL}\end{array}$ \\
\hline \multicolumn{7}{|c|}{ PIP kinase } \\
\hline $\begin{array}{l}\text { Type I PIPK (PI4P 5-kinase) } \\
\text { PI4P 5-kinase, type I } \alpha\end{array}$ & NO 003548 & 549 & 3 & 50IPQTP & none & $\begin{array}{l}\text { 376RNSKGERLLL } \\
\text { 379 KGERLLLYI }\end{array}$ \\
\hline $\begin{array}{l}\text { PI4P 5-kinase, type I } \beta \\
\text { PI4P 5-kinase type } l \gamma\end{array}$ & $\begin{array}{l}\text { NP } 003549 \\
\text { NP } 036530 \\
\end{array}$ & $\begin{array}{l}540 \\
668\end{array}$ & $\begin{array}{l}4 \\
6\end{array}$ & $\begin{array}{l}\text { 464PSTP } \\
\text { 510PCTP }\end{array}$ & $\begin{array}{l}\text { none } \\
\text { none }\end{array}$ & $\begin{array}{l}\text { 379 KGERLLLYIGI } \\
\text { 335KSHRGEKLLL } \\
\text { 386RGERLLLHI } \\
\text { 386RGERLLLHIGI }\end{array}$ \\
\hline $\begin{array}{c}\text { Type III PIPK (PIKfyve; PI3P 5-kinase) } \\
\text { PIKfyve }\end{array}$ & Q9Y217 & 2098 & 32 & $\begin{array}{l}\text { 18PRSP } \\
\text { 21PTSP } \\
\text { 32PLTP } \\
\text { 25IPRTP } \\
\text { 58IPFTP } \\
\text { 1524PPSP }\end{array}$ & none & $\begin{array}{c}{ }^{259} \mathrm{KASRNIFL} \\
\text { 700KNPKILLL } \\
1981 \mathrm{KMVRDNPLYI}\end{array}$ \\
\hline \multicolumn{7}{|c|}{$\operatorname{Ins}(I, 4,5) P_{3}$ 3-kinase } \\
\hline $\operatorname{Ins}(I, 4,5) P_{3}$ 3-kinase $B$ & $\underline{P 27987}$ & 946 & 24 & $\begin{array}{l}\text { 69PRSP } \\
\text { 164PRSP } \\
\text { 262PASP }\end{array}$ & 56FLFP & 665KKKYPWIQL \\
\hline \multicolumn{7}{|c|}{$\operatorname{lns}(1,3,4,5,6)_{5} 2$-kinase } \\
\hline $\operatorname{lns}(1,3,4,5,6)_{5}$ 2-kinase & AAM75353 & 491 & 5 & none & 240 FFFP & none \\
\hline
\end{tabular}


Table 2: Kinases (human) that do not have an FXFP motif and/or D-domain sequence. Kinases that use phosphatidylinositols or inositols as substrates and do not contain an FXFP or D-domain sequence are listed in the table; all sequences are for human proteins. The number of potential MAPK phosphorylation sites and sequences fitting the optimal MAPK phosphorylation in these kinases are also identified.

\begin{tabular}{|c|c|c|c|c|}
\hline Isozyme & $\begin{array}{c}\text { GenBank } \\
\text { Accession \# }\end{array}$ & \# amino acids & $\begin{array}{l}\text { number of } \\
(\mathrm{S} / \mathrm{T}) \mathrm{P} \text { sites }\end{array}$ & $\begin{array}{l}\text { Site(s) with the consensus } \\
\text { PX(S/T)P sequence }\end{array}$ \\
\hline PI 3-kinase $\beta$ & NP 006210 & 1070 & 3 & none \\
\hline PI 3-kinase, $C 2-\beta$ & $\underline{000750}$ & 1634 & 17 & none \\
\hline PIP kinase Type Il $\alpha$ & NP 005019 & 406 & 5 & 314PDSP \\
\hline PIP kinase Type li $\beta$ & $\underline{P 78356}$ & 416 & 4 & 324PDSP \\
\hline PIP kinase Type li & NP 079055 & 421 & I & none \\
\hline Ins $(1,4,5) P_{3} 3$-kinase $A$ & $\underline{P 23677}$ & 461 & 4 & $\begin{array}{l}\text { 18PCSP } \\
\text { 93PTSP }\end{array}$ \\
\hline Ins $(1,4,5) P_{3}$ 3-kinase $C$ & $\underline{N P} 079470$ & 683 & 8 & 334PETP \\
\hline $\operatorname{lns}(I, 3,4) P_{3} 5 / 6$-kinase $/ \operatorname{lns}(3,4,5,6) P_{4}$ I-kinase & $\overline{N P 055031}$ & 414 & 3 & none \\
\hline Inositol polyphosphate multikinase/Ins $(1,3,4,6) \mathrm{P}_{4}$ 5-kinase & Q8NFU5 & 416 & 5 & none \\
\hline
\end{tabular}

tion state of the inositol ring in PIs and IPs from GenBank at NCBI and searched these sequences for an FXFP motif and the two consensus sequences for a D-domain reported by Kornfeld and colleagues [4]: (K/R)X(X/K/ $\mathrm{R})(\mathrm{K} / \mathrm{R}) \mathrm{X}_{(1-4)}(\mathrm{L} / \mathrm{I}) \mathrm{X}(\mathrm{L} / \mathrm{I})$ or $(\mathrm{K} / \mathrm{R})(\mathrm{K} / \mathrm{R})(\mathrm{K} / \mathrm{R}) \mathrm{X}_{(1-5)}(\mathrm{L} /$ I) $\mathrm{X}(\mathrm{L} / \mathrm{I})$. We note that this strategy most likely failed to identify all possible sequences that may function as MAPK docking sites. For example, both the human and mouse Class I PI 3-kinase $\beta$ include the sequence LILRRHGNLFI, which contains a KIM, as defined by MacKenzie et al [16], and a MAPK-docking site, as defined by Bardwell et al. [16], but not a D-domain according to the criteria that we employed. Similarly, the human and mouse Ins $(1,3,4) \mathrm{P}_{3}$ $5 / 6$-kinase/Ins $(3,4,5,6)$ 1-kinase contain the sequence LCRKRGXEVVQLNL ( $\mathrm{X}$ is $\mathrm{M}$ in human and I in mouse), which fits the consensus sequences for a KIM and a MAPKbinding site, but not a D-domain. We chose to use the criteria of Kornfeld and colleagues based on its successful application in the identification of D-domains in PLC isozymes $[25,26]$. Although the list that we have compiled is likely to be incomplete, it does serve as a useful first approximation. We also searched each of the enzyme sequences for potential MAPK phosphorylation sites (i.e., (S/T)P sequences) and MAPK optimal phosphorylation sequences, PX(S/T)P. Finally, we note that we did not analyze the sequences of enzymes that control the metabolism of the diphosphorylated IPs.

\section{Presentation of the data}

In order to facilitate the presentation of the data, we separated human from mouse enzymes, kinases from phosphatases, and enzymes in which we identified a Ddomain and/or FXFP motif from those in which we did not. Human and mouse kinases having a D-domain and/ or FXFP motif are contained in Tables 1 and 3, respectively, whereas human and mouse kinases that do not have either of these sequences are presented in Tables 2 and 4, respectively. Similarly, human and mouse phosphatases containing a D-domain and/or FXFP motif are listed in Tables 6 and 8, respectively, while human and mouse phosphatases that are devoid of these sequences are contained in Tables 7 and 9, respectively.

In the following discussion we use the terms "alternative pair" and "overlapping" in referring to relationships of Ddomains. An alternative pair of D-domains has the same amino-terminus and two possible carboxyl-termini: e.g., 15RRRDAVIAL and 15RRRDAVIALGI in human PI 4kinase $\alpha$ (Table 1$)$. We use the term overlapping to identify D-domains that have distinct amino-termini and carboxyl-termini, but share a region of sequence: e.g., 376RNSKGERLLL and 379KGERLLLYI found in human PI4P 5-kinase type I $\alpha$ (Table 1).

\section{PI 3-kinase}

Phosphatidylinositol 3-kinase (also called phosphoinositide 3-kinase, PtdIns 3-kinase, PI 3-kinase, and PI3K) isozymes catalyze the phosphorylation of the 3-position of the inositol ring of phosphatidylinositols [32]. Three classes (I, II, and III) of PI 3-kinase have been identified $[38,39]$. These classes are differentiated on the basis of their subunit composition, substrate specificity and mechanisms of regulation. The Class I enzymes are heterodimers of a regulatory subunit, of various sizes, and a catalytic subunit of approximately $110 \mathrm{kDa}$. Three distinct forms of

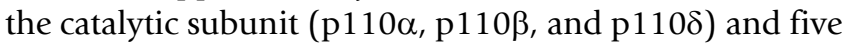
forms of the regulatory subunit (p85 $\alpha, \mathrm{p} 85 \beta, \mathrm{p} 55 \alpha, \mathrm{p} 55 \gamma$, and $\mathrm{p} 50 \alpha$ ) have been identified. The class IB isoform consists of a p101 regulatory subunit coupled to a p100 $\gamma$ catalytic subunit. Class I enzymes catalyze the synthesis of PtdIns3P, PtdIns $(3,4) \mathrm{P}_{2}$, and PtdIns $(3,4,5) \mathrm{P}_{3}[40,41]$; PtdIns $(4,5) \mathrm{P}_{2}$ may be the preferred substrate in vivo [42]. 
Table 3: Kinases (mouse) that have an FXFP motif and/or D-domain sequence. The number of potential MAPK phosphorylation sites, sequences fitting the optimal MAPK phosphorylation consensus sequence of PX(S/T)P, and FXFP motifs and D-domain sequences in kinases that use phosphatidylinositols or inositols as substrates are listed in the table; all sequences are for mouse proteins.

\begin{tabular}{|c|c|c|c|c|c|c|}
\hline Isozyme & $\begin{array}{c}\text { GenBank } \\
\text { Accession \# }\end{array}$ & \# amino acids & \# $(\mathrm{S} / \mathrm{T}) \mathrm{P}$ sites & $\begin{array}{l}\text { Site(s) with the consensus } \\
\mathrm{PX}(\mathrm{S} / \mathrm{T}) \mathrm{P} \text { sequence }\end{array}$ & FXFP motif & D-domain motif \\
\hline \multicolumn{7}{|c|}{ PI 3-kinase } \\
\hline \multicolumn{7}{|l|}{ Class I } \\
\hline PI 3-kinase $\alpha$ & NP 032865 & 1068 & 6 & none & none & $\begin{array}{l}{ }^{27 I} \mathrm{KYIRSCIML} \\
\text { 398RLARLCLSI }\end{array}$ \\
\hline PI 3-kinase $\gamma$ & NP 064668 & 1102 & 12 & none & none & 807KKKPLWL \\
\hline \multicolumn{7}{|l|}{ Class II } \\
\hline PI 3-kinase, C2- $\alpha$ & NP 035213 & 1509 & 13 & $\begin{array}{l}\text { 24PLTP } \\
\text { 27PATP } \\
\text { 1374PFSP }\end{array}$ & none & ${ }^{63} \mathrm{KNGKARTDLEI}$ \\
\hline PI 3-kinase, C2- $\gamma$ I & NP 997566 & 1506 & 12 & none & none & $\begin{array}{l}\text { 930KDIKTCHLPL } \\
\text { 1409 KHLKNIHL }\end{array}$ \\
\hline PI 3-kinase, C2- $\gamma 2$ & NP 035214 & 653 & 3 & none & none & $\begin{array}{l}\text { 77KDIKTCHLPL } \\
556 \mathrm{KHLKNIHL}\end{array}$ \\
\hline \multicolumn{7}{|l|}{ Class III } \\
\hline PI 3-kinase Vps34-type & NP 852079 & 887 & 4 & none & none & ${ }^{656} \mathrm{KLLRKENLDL}$ \\
\hline \multicolumn{7}{|c|}{ PI 4-kinase } \\
\hline PI 4-kinase $\alpha$ (PI4K230) & NP 001001983 & 2044 & 16 & $\begin{array}{l}\text { 215PSSP } \\
\text { 590PPSP }\end{array}$ & 1822FVFP & $\begin{array}{l}\text { 15RRRDAVIAL } \\
\text { 15RRRDAVIALGI } \\
\text { 1340KRLREDISI } \\
\text { 1340KRLREDISIMI } \\
\text { 1429 KRRTLLL } \\
{ }^{1429} \mathrm{KRRTLLLSL}\end{array}$ \\
\hline PI 4-kinase $\beta$ (PI4K92) & NP 780565 & 801 & 8 & none & none & $\begin{array}{c}\text { 232RGTKLRKLIL } \\
\text { 333KTQRLISELSL } \\
581 \text { KPYKILVI }\end{array}$ \\
\hline $\begin{array}{l}\text { PI 4-kinase type II } \\
\text { (PI4K55) }\end{array}$ & NP 663476 & 479 & 5 & ${ }^{49} \mathrm{PCSP}$ & none & ${ }^{435} \mathrm{KDNKSPLHL}$ \\
\hline \multicolumn{7}{|c|}{ PIP kinase } \\
\hline \multicolumn{7}{|l|}{ Type I PIPK (PI4P 5-kinase) } \\
\hline PI4P 5-kinase, type la & NP 032872 & 539 & 3 & 464PSTP & none & ${ }^{335} \mathrm{KSHRGEKLLL}$ \\
\hline PI4P 5-kinase type I $\beta$ & NP 032873 & 546 & 5 & 498PQTP & none & $\begin{array}{c}{ }^{374} \mathrm{RNNKGERLLL} \\
{ }^{377} \mathrm{KGERLLLYI} \\
{ }^{377} \mathrm{KGERLLLYIGI}\end{array}$ \\
\hline PI4P 5-kinase type $l \gamma$ & NP 032870 & 661 & 5 & 509PCTP & none & $\begin{array}{l}\text { 386RGERLLLHI } \\
\text { 386RGERLLLHIGI }\end{array}$ \\
\hline \multicolumn{7}{|c|}{ Type III PIPK (PIKfyve; PI3P 5-kinase) } \\
\hline PIKfyve & NP 035216 & 2052 & 31 & $\begin{array}{l}\text { 18PRSP } \\
\text { 21PASP } \\
\text { 32PLTP } \\
\text { 262PRTP } \\
\text { 536PFTP } \\
\text { 1479PPSP }\end{array}$ & none & $\begin{array}{c}{ }^{270} \mathrm{KASRNIFL} \\
655 \mathrm{KNPKILLL} \\
1935 \mathrm{KMVRDNPLYI}\end{array}$ \\
\hline
\end{tabular}

Class II isozymes are monomeric catalytic subunits $(\alpha, \beta$, and $\gamma$ ) containing a carboxyl-terminal C2 domain; these enzymes may be referred to as PI3K-C2. PtdIns and PtdIns4P, and under certain conditions PtdIns $(4,5) \mathrm{P}_{2}$, are substrates for the Class II PI 3-kinase [39,43]. A single
Class III isozyme, which is specific for PtdIns, has been identified

The Class I $\mathrm{p} 110 \alpha$ and $\mathrm{p} 110 \gamma$ human (Table 1 ) and mouse (Table 3) proteins contain D-domains, whereas the $\mathrm{p} 110 \beta$ 
Table 4: Kinases (mouse) that do not have an FXFP motif and/or D-domain sequence. Kinases that use phosphatidylinositols or inositols as substrates and do not contain an FXFP or D-domain sequence are listed in the table; all sequences are for mouse proteins. The number of potential MAPK phosphorylation sites and sequences fitting the optimal MAPK phosphorylation in these kinases are also identified.

\begin{tabular}{|c|c|c|c|c|}
\hline Isozyme & GenBank Accession \# & \# amino acids & \# $(\mathrm{S} / \mathrm{T}) \mathrm{P}$ sites & $\begin{array}{l}\text { Site(s) with the consensus } \\
\text { PX(S/T)P sequence }\end{array}$ \\
\hline PI 3-kinase $\beta$ & NP 083370 & 1064 & 4 & none \\
\hline PI 3-kinase $\delta$ & NP 032866 & 1043 & 3 & none \\
\hline PI 4-kinase type II- $\beta$ (PI4K55) & NP 083020 & 445 & 2 & none \\
\hline PIP kinase Type li $\alpha$ & NP 032871 & 405 & 4 & 314PDSP \\
\hline PIP kinase Type li $\beta$ & $\mathrm{Q} 80 \times 14$ & 416 & 3 & 324PDSP \\
\hline PIP kinase Type li $\gamma$ & NP 473438 & 421 & 2 & none \\
\hline $\operatorname{lns}(I, 4,5) P_{3}$ 3-kinase $A$ & Q8R07I & 459 & 5 & $\begin{array}{l}\text { 18PCSP } \\
\text { 92PASP }\end{array}$ \\
\hline $\operatorname{lns}(I, 4,5) P_{3}$ 3-kinase $C$ & NP 853624 & 678 & 8 & 328PETP \\
\hline $\operatorname{lns}(I, 3,4) \mathrm{P}_{3} 5 / 6$-kinase $/ \operatorname{lns}(3,4,5,6) \mathrm{P}_{4} \mathrm{I}$-kinase & NP 766172 & 419 & 4 & none \\
\hline Inositol polyphosphate multikinase/lns $(I, 3,4,6) \mathrm{P}_{4}$-kinase & Q7TTI6 & 396 & 2 & none \\
\hline
\end{tabular}

(Tables 2 and 4) and p110 (Tables 1 and 4) isozymes do not. Of all the PI 3-kinase sequences that we analyzed, only the human PI 3-kinase $\delta$ (Table 1 ) contains an FXFP motif ( ${ }^{585}$ FSFP).

The Class II PI3-kinase C2- $\alpha$ contains a D-domain that is conserved in the human (Table 1) and mouse (Table 3 ) isozymes. PI 3-kinase C2- $\alpha$ was the only PI 3-kinase isozyme in which we found an optimal MAPK phosphorylation sequence (Tables 1, 2, 3, 4). The human and mouse PI 3-kinase C2- $\alpha$ proteins each contain three such sequences; a sequence alignment revealed that two of these (PLTP and PATP) are conserved, while the third, ${ }^{118}$ PVTP and ${ }^{1374}$ PFSP in human and mouse, respectively, is unique. Both the human (Table 1) and mouse (Table 3 ) PI 3-kinase C2- $\gamma$ contain D-domains. A sequence align-

Table 5: Reactions catalyzed by PIP kinases (based on [50] and [5I])

\begin{tabular}{l}
\hline Type I PIP kinase \\
\hline $\mathrm{PI} \rightarrow \mathrm{PI} 5 \mathrm{P}$ \\
$\mathrm{PI} 3 \mathrm{P} \rightarrow \mathrm{PI}(3,4) \mathrm{P}_{2}$ \\
$\mathrm{PI} 4 \mathrm{P} \rightarrow \mathrm{PI}(4,5) \mathrm{P}_{2}$ \\
$\mathrm{PI} 3 \mathrm{P} \rightarrow \rightarrow \mathrm{PI}(3,4,5) \mathrm{P}_{3}$ \\
$\mathrm{PI}(3,4) \mathrm{P}_{2} \rightarrow \mathrm{PI}(3,4,5) \mathrm{P}_{3}$ \\
\hline Type II PIP kinase \\
\hline $\mathrm{PI} 3 \mathrm{P} \rightarrow \mathrm{PI}(3,4,) \mathrm{P}_{2}$ \\
$\mathrm{PI} 5 \mathrm{P} \rightarrow \mathrm{PI}(4,5) \mathrm{P}_{2}$ \\
$\mathrm{PI} 3 \mathrm{P} \rightarrow \rightarrow \mathrm{PI}(3,4,5) \mathrm{P}_{3}$ \\
\hline Type III \\
\hline $\mathrm{PI} \rightarrow \mathrm{PI} 5 \mathrm{P}$ \\
$\mathrm{PI} 3 \mathrm{P} \rightarrow \mathrm{PI}(3,5) \mathrm{P}_{2}$
\end{tabular}

ment of these two proteins revealed that only the last Ddomain (1347KHMKNIHL in human and ${ }^{1409}$ KHLKNIHL in mouse) aligns; all of the other identified D-domains are unique to one or the other protein. These results indicate the MAPK-dependent regulation of the human and mouse Class II PI 3-kinases may be significantly different and, thus, caution should be exercised when comparing studies on these two proteins.

The human (Table 1) and mouse (Table 3) Class III PI 3kinase contains a conserved D-domain. Neither of these proteins contains an FXFP motif or an optimal phosphorylation sequence for MAPKs.

\section{PI 4-kinase}

Phosphatidylinositol 4-kinase (PtdIns 4-kinase, PI 4kinase) catalyzes the phosphorylation of PtdIns to produce PtdIns4P. Subfamilies (Types II and III; or PI4K230, PI4K92 and PI4K55 using the nomenclature of Heilmeyer et al. [45]) of PI 4-kinase have been identified; these posses a conserved C-terminal catalytic domain and diverse $\mathrm{N}$-terminal regulatory domains [45]. Differing physiologic functions have been ascribed to each of the three subfamilies [45-49].

PI4Ka (also called PI 4-kinase 230) contains three alternative pairs of D-domains that are conserved in human (Table 1) and mouse (Table 3 ) sequences. PI4K $\alpha$ also contains an FXFP sequence and two optimal MAPK phosphorylation sequences that are conserved in human and mouse proteins. PI 4-kinase $\beta$ (also called PI 4-kinase 92) contains three $\mathrm{D}$-domains that are conserved in the human (Table 1) and mouse (Table 3) isozymes. The first of these (232RGTKLRKLIL) overlaps with an identifiable bipartite nuclear localization sequence motif [45]. The human and mouse PI 4-kinase- $\beta$ do not contain an FXFP motif or optimal MAPK phosphorylation sequence. The 
Table 6: Phosphatases (human) that have an FXFP motif and/or D-domain sequence. The number of potential MAPK phosphorylation sites, sequences fitting the optimal MAPK phosphorylation consensus sequence of PX(S/T)P, and FXFP motifs and D-domain sequences in phosphatases that use phosphatidylinositols or inositols as substrates are listed in the table; all sequences are for human proteins.

\begin{tabular}{|c|c|c|c|c|c|c|}
\hline Isozyme & $\begin{array}{c}\text { GenBank } \\
\text { Accession \# }\end{array}$ & $\begin{array}{l}\text { \# amino } \\
\text { acids }\end{array}$ & $\begin{array}{l}\text { \# }(\mathrm{S} / \mathrm{T}) \mathrm{P} \\
\text { sites }\end{array}$ & $\begin{array}{c}\text { Site }(s) \text { with the } \\
\text { consensus } \mathrm{PX}(\mathrm{S} / \mathrm{T}) \mathrm{P} \\
\text { sequence }\end{array}$ & $\begin{array}{l}\text { FXFP } \\
\text { motif }\end{array}$ & D-domain motif \\
\hline \multicolumn{7}{|c|}{ monophosphatase } \\
\hline inositol monophosphatase Al & NP 005527 & 277 & 2 & none & none & 26IRIAKEIQVIPL \\
\hline \multicolumn{7}{|c|}{ I-phosphatase } \\
\hline Inositol polyphosphate I-phosphatase & P4944I & 399 & 1 & none & none & ${ }^{378}$ RKRLETFLSL \\
\hline \multicolumn{7}{|c|}{ 3-phosphatase } \\
\hline $\begin{array}{c}\text { Myotubularin-related protein I isoform I; } \\
\text { MTMRI-I }\end{array}$ & NP 003819 & 665 & 3 & none & none & 177KDMRNLRL \\
\hline $\begin{array}{l}\text { Myotubularin-related protein I isoform 2; } \\
\text { MTMRI-2 }\end{array}$ & NP 789746 & 568 & 2 & none & none & 177KDMRNLRL \\
\hline $\mathrm{PI}(3,4,5) \mathrm{P}_{3}$ 3-phosphatase, PTEN & $\underline{\mathrm{P} 60484}$ & 403 & 2 & none & ${ }^{24 I}$ FEFP & none \\
\hline \multicolumn{7}{|c|}{ 4-phosphatase } \\
\hline Inositol polyphosphate 4-phosphatase, Type la & NP 004018 & 938 & 7 & none & none & 147RHHRLHLTL \\
\hline Inositol polyphosphate 4-phosphatase, Type lb & NP 001557 & 954 & 8 & none & none & ${ }^{147}$ RHHRLHLTL \\
\hline Inositol polyphosphate 4-phosphatase, Type l $\alpha 3$ & $\underline{\mathrm{AAK} 58870}$ & 977 & 7 & none & none & 147RHHRLHLTL \\
\hline SACI poly-phosphatidylinositol phosphatase & $\widehat{\mathrm{AAQH} 16559}$ & 587 & 3 & none & none & $\begin{array}{l}{ }^{345} \mathrm{KNMRWDRLSI} \\
\text { 348RWDRLSILL } \\
\text { 461RTGKRTHLGL } \\
\text { 517RDWKFLAL } \\
\text { 517RDWKFLALPI }\end{array}$ \\
\hline
\end{tabular}

5-phosphatase

Group II

Inositol polyphosphate 5-phosphatase OCRL-I Inositol polyphosphate 5-phosphatase OCRL-2 Synaptojanin 2 (synaptic inositol I,4,5trisphosphate 5-phosphatase 2)

Sac-domain-containing inositol phosphatase 2 isoform I; inositol polyphosphate 5-phosphatase $\mathrm{F}$ isoform I

Sac-domain-containing inositol phosphatase 3 Inositol polyphosphate 5-phosphatase, $75 \mathrm{kDa}$

Inositol polyphosphate 5-phosphatase, 75 kDa; Inositol polyphosphate 5-phosphatase B

Inositol polyphosphate 5-phosphatase, $145 \mathrm{kDa}$;

$\mathrm{PI}(3,4,5) \mathrm{P}_{3}$ 5-phosphatase; $\mathrm{SH} 2$-containing Group IV inositol 5'-phosphatase I; SHIPI

PI polyphosphate 5-phosphatase type IV; Inositol polyphosphate 5-phosphatase E

\begin{tabular}{|c|c|c|c|c|c|}
\hline Q01968 & 901 & 3 & none & none & ${ }^{446 R L L K F D Q L N I ~}$ \\
\hline NP 001578 & 893 & 3 & none & none & ${ }^{446}$ RLLKFDQLNI \\
\hline O15056 & 1496 & 17 & $\begin{array}{l}\text { 987PVSP } \\
\text { 1218PETP } \\
\text { 1249PLSP }\end{array}$ & none & ${ }^{617}$ RSHRYILL \\
\hline NP 055752 & 1132 & 12 & ${ }^{259}$ PETP & none & ${ }^{85} \mathrm{KVTKIAVLSL}$ \\
\hline NP 055660 & 907 & 5 & none & none & ${ }^{663} \mathrm{KFHKYEEEIDI}$ \\
\hline NP 005531 & 748 & 5 & none & none & $\begin{array}{c}31 \text { RQSRLLGL } \\
335 \mathrm{KYAKVKLIRL} \\
340 \mathrm{KLIRLVGIML}\end{array}$ \\
\hline NP 032411 & 993 & 5 & none & none & $\begin{array}{c}31 \text { RQSRLLGL } \\
\text { 420KFVRLVGIML }\end{array}$ \\
\hline & Group III & & & & \\
\hline NP 005532 & 1188 & 18 & $\begin{array}{l}\text { 286PESP } \\
\text { 960PPTP 968PISP } \\
\text { I133PPTP }\end{array}$ & none & ${ }^{348} \mathrm{KSQKFLNKLVI}$ \\
\hline$\underline{\text { AAF8I } 404}$ & 644 & 10 & 55PATP 239PRSP & none & $\begin{array}{l}\text { 79RLERALSL } \\
\text { 596RPGRDNIPL } \\
\text { 608KFDRELYL } \\
\text { 608 KFDRELYLLGI }\end{array}$ \\
\hline
\end{tabular}


human (Table 1) and mouse (Tabl3 3) PI 4-kinase type II (also called PI 4-kinase 55) contain a conserved Ddomain and optimal phosphorylation sequence for a MAPK. Neither protein contains an FXFP motif. The human (Table 1), but not the mouse (Table 4), PI 4kinase type II- $\beta$ contains a single D-domain, while neither protein contains a sequence fitting the MAPK optimal phosphorylation sequence or the FXFP motif.

\section{PIP kinase}

Phosphatidylinositol phosphate kinases (PIP kinases, PIPKs) utilize PtdIns3P, PtdIns4P, and PtdIns5P as substrates, catalyzing the synthesis of $\operatorname{PtdIns}(3,4) \mathrm{P}_{2}$, $\operatorname{Ptd} I n s(3,5) \mathrm{P}_{2}$, and $\operatorname{PtdIns}(4,5) \mathrm{P}_{2}$ (Table 5). These enzymes are also able to catalyze the formation of PtdIns5P and PtdIns $(3,4,5) \mathrm{P}_{3}$ (Table 5). Three types (I, II and III) of PIP kinase are defined based on primary sequence, substrate specificity, and subcellular localization [51]. These families are often designated by the reaction that they catalyze most efficiently. Thus, the Type I PIP kinases are also termed PI4P 5-kinase, the Type II PIP kinases are termed PI5P 4-kinases, and the Type III PIP kinases are called PI3P 5-kinases. Three forms (termed $\alpha$, $\beta$, and $\gamma$ ), each with multiple splice variants, of Type I and Type II PIP kinase have been identified [52-55]. It should be noted that the nomenclature for the $\alpha$ - and $\beta$-forms of the human and mouse Type I PIP kinase are reversed: that is, the human Type I $\alpha$ enzyme corresponds to the mouse Type $I \beta$ enzyme, and vice versa.

Each of the Type I isozymes contain at least one identifiable D-domain that was conserved in humans and in mice. In human PI4P 5-kinase Type I $\alpha$ (Table 1) an alternative pair of D-domains ( ${ }^{379}$ KGERLLLYI and ${ }^{379}$ KGERLLLYIGI) overlaps with a different D-domain (376RNSKGERLLL). This observation raises the intriguing possibility that these sequences are specific for binding of a particular MAPK, or MAPK family, and that there is competition among MAPKs for binding, with the likelihood that a mechanism(s) exists for the regulation of this binding. Further, the MAPK that is bound may affect the kinetics of the signal that is generated and, thus, the downstream response. The identified alternative pair of D-domains in PI4P 5kinase type I $\gamma$ (PIPKI $\gamma$ ) (Tables 1 and 3 ) may be responsible for binding phospho-ERK1, which has been shown to catalyze the phosphorylation of serine 650 in PIPKI $\gamma$ [56]. Phosphorylation of serine 650 inhibits the binding of talin to PIPKI $\gamma$ and may play a role in synaptic neurotransmission and focal adhesion disassembly during mitosis. None of the Type I PIP kinases that we analyzed contains an FXFP motif (Tables 1 and 3). Each of the Type I PIPKs that we analyzed contains an optimal MAPK phosphorylation site that is conserved in human and mouse proteins. In the case of PIPKI $\gamma$, this is not serine-650. However, it is possible that other MAPKs are capable of phosphorylating threonine-512 (human)/threonine-511 (mouse).

The Type II isozymes (Tables 2 and 4 ) were found to be devoid of D-domain sequences and FXFP motifs. However, the Type II $\alpha$ and Type II $\beta$ isozymes do contain an optimal MAPK phosphorylation sequence that is conserved in human (Table 2) and mouse (Table 4) protein sequences.

The PIKfyve human (Table 1) and mouse (Table 3) sequences each contain six MAPK optimal phosphorylation sequences. This is the most that we found in any of the sequences that we analyzed. These enzymes contain three conserved D-domain sequences, but are devoid of an FXFP motif.

\section{Ins $(I, 4,5) P_{3}$ 3-kinase}

Ins $(1,4,5) \mathrm{P}_{3}$ 3-kinase catalyzes the formation of $\operatorname{Ins}(1,3,4,5) \mathrm{P}_{4}$ from $\operatorname{Ins}(1,4,5) \mathrm{P}_{3}$. Three forms of Ins $(1,4,5) \mathrm{P}_{3} 3$-kinase have been cloned; these forms differ in their molecular mass, regulation by $\mathrm{Ca}^{2} /$ calmodulin, tissue distribution and intracellular localization [57-64]. All three forms of human (Tables 1 and 2) and both forms of mouse (Table 4) Ins $(1,4,5) \mathrm{P}_{3} 3$-kinase contain one or more optimal sequence for MAPK phosphorylation. Human Ins $(1,4,5) \mathrm{P}_{3}$ 3-kinase $\mathrm{B}$ contains both an FXFP motif and a D-domain, whereas the $\mathrm{A}$ and $\mathrm{C}$ isoforms do not contain either of these two MAPK docking sequences (Tables 1 and 2). Ins $(1,4,5) \mathrm{P}_{3} 3$-kinase $\mathrm{B}$, which plays a critical role in T-cell development $[65,66]$, is associated with the endoplasmic reticulum via its $\mathrm{N}$-terminus $[57,67]$. Thus, it is possible that the MAPK binding to the ${ }^{56} \mathrm{FLFP}$ sequence motif and/or phosphorylation of serine71 within the optimal phosphorylation sequences (69PRSP) regulates $\operatorname{Ins}(1,4,5) \mathrm{P}_{3}$ 3-kinase $\mathrm{B}$ interaction with the endoplasmic reticulum.

\section{Ins $(I, 3,4) P_{3}$ 5/6-kinase/Ins(3,4,5,6) I-kinase}

Wilson and Majerus [68] cloned an $\operatorname{Ins}(1,3,4) \mathrm{P}_{3} 5 / 6$ kinase, which was subsequently shown by Yang and Shears [69] to be the same as $\operatorname{Ins}(3,4,5,6) \mathrm{P}_{4} 1$-kinase. Interestingly, this enzyme also possesses $\operatorname{Ins}(1,3,4,5,6) \mathrm{P}_{5}$ 1-phosphatase activity [70]. Regulation of these latter two reciprocal activities provides a mechanism for tight control of Ins $(3,4,5,6) \mathrm{P}_{4}$ levels in cells. The production of Ins $(1,3,4,6) \mathrm{P}_{4}$ by Ins $(1,3,4) \mathrm{P}_{3} 5 / 6$-kinase is the rate-limiting step in the synthesis of inositol hexakisphosphate from Ins $(1,3,4) \mathrm{P}_{3}[71]$. We were unable to identify an optimal sequence for MAPK phosphorylation, an FXFP motif or a D-domain in human (Table 2 ) or mouse (Table 4) Ins $(1,3,4) \mathrm{P}_{3} 5 / 6$-kinase/Ins $(3,4,5,6)$ 1-kinase. 
Table 7: Phosphatases (human) that do not have an FXFP motif and/or D-domain sequence. Phosphatases that use phosphatidylinositols or inositols as substrates and do not contain an FXFP or D-domain sequence are listed in the table; all sequences are for human proteins. The number of potential MAPK phosphorylation sites and sequences fitting the optimal MAPK phosphorylation in these kinases are also identified.

\begin{tabular}{|c|c|c|c|c|}
\hline Isozyme & GenBank Accession \# & \# amino acids & \# (S/T)P sites & $\begin{array}{l}\text { Site(s) with the consensus } \\
\mathrm{PX}(\mathrm{S} / \mathrm{T}) \mathrm{P} \text { sequence }\end{array}$ \\
\hline inositol monophosphatase $\mathrm{A} 2$ & NP 055029 & 288 & 1 & none \\
\hline inositol monophosphatase $\mathrm{A} 3$ & NP 060283 & 359 & 3 & none \\
\hline Myotubularin; MTMI & Q13496 & 603 & 3 & $\begin{array}{l}586 \text { PTSP } \\
\text { 589PSSP }\end{array}$ \\
\hline Myotubularin-related protein 2; MTMR2 & Q13614 & 643 & 4 & none \\
\hline Myotubularin-related protein 3; MTMR3 & $\underline{Q} 13615$ & 1198 & 9 & 582PTTP \\
\hline Myotubularin-related protein 6; MTMR6 & Q9Y217 & 621 & 3 & 559PESP \\
\hline Inositol polyphosphate 4-phosphatase, Type II & NP 003857 & 924 & 7 & 485PPSP \\
\hline Inositol I,4,5-trisphosphate 5-phosphatase, Type I & Q14642 & 412 & 3 & none \\
\hline $\begin{array}{c}\text { Synaptojanin I (synaptic inositol I,4,5-trisphosphate 5- } \\
\text { phosphatase I) }\end{array}$ & $\underline{043426}$ & 1575 & 23 & $\begin{array}{l}\text { 1090PATP } \\
\text { II48PPSP } \\
\text { 1161PKSP }\end{array}$ \\
\hline $\begin{array}{l}\text { Sac-domain-containing inositol phosphatase } 2 \text { isoform } 2 \text {; } \\
\text { inositol polyphosphate } 5 \text {-phosphatase } \mathrm{F} \text { isoform } 2\end{array}$ & NP 938|44 & 500 & 8 & none \\
\hline $\begin{array}{l}\text { Sac-domain-containing inositol phosphatase } 2 \text { isoform } 3 \text {; } \\
\text { inositol polyphosphate } 5 \text {-phosphatase } \mathrm{F} \text { isoform } 3\end{array}$ & NP 938145 & 219 & 1 & none \\
\hline $\mathrm{PI}(4,5) \mathrm{P}_{2}$ 5-phosphatase A; PIB5PA; PIPP & Q15735 & 1006 & 26 & $\begin{array}{l}\text { 148PRSP } \\
\text { 199PSTP } \\
\text { 345PRSP }\end{array}$ \\
\hline $\begin{array}{c}\text { Skeletal muscle and kidney enriched inositol phosphatase } \\
\text { isoform I; SKIP I }\end{array}$ & NP 057616 & 448 & 4 & $\begin{array}{l}\text { 283PDTP } \\
\text { 356PSSP }\end{array}$ \\
\hline $\begin{array}{c}\text { Skeletal muscle and kidney enriched inositol phosphatase } \\
\text { isoform 2; SKIP } 2\end{array}$ & NP 570122 & 372 & 4 & $\begin{array}{l}\text { 207PDTP } \\
\text { 280PSSP }\end{array}$ \\
\hline $\begin{array}{c}\text { Phospholipids-inositol phosphatase; PTEN-like phosphatase; } \\
\text { PLIP; PTPMI }\end{array}$ & $\mathrm{AAH} 20242$ & 201 & I & none \\
\hline $\begin{array}{c}\text { Inositol polyphosphate 5-phosphatase 2; SH2-containing } \\
\text { inositol 5'-phosphatase 2; SHIP2 }\end{array}$ & $\mathrm{JC} 5765$ & 1258 & 7 & $\begin{array}{l}\text { 156PSSP } \\
\text { 163PETP } \\
\text { 956PLTP } \\
1001 \text { PPSP }\end{array}$ \\
\hline
\end{tabular}

Inositol polyphosphate multikinase/Ins $(I, 3,4,6) P_{4}$ 5-kinase Inositol polyphosphate multikinase catalyzes the formation of Ins $(1,3,4,5,6) \mathrm{P}_{5}$ from Ins $(1,4,5) \mathrm{P}_{3}$ by phosphorylation of both the 3- and 6-position of the inositol ring $[30,36]$, with phosphorylation of the 3 -position possibly preceding that of the 6-position [72]. The enzyme also phosphorylates the 1-position of $\operatorname{Ins}(4,5) \mathrm{P}_{2}$ to form Ins $(1,4,5) \mathrm{P}_{3}[72]$. Majerus and colleagues [73] reported that in vitro the enzyme displays specificity as an Ins $(1,3,4,6)$ 5-kinase. Neither the human (Table 2) nor mouse (Table 4 ) protein contains an FXFP motif, a Ddomain or optimal sequence for MAPK phosphorylation.

\section{Ins $(I, 3,4,5,6)$ 2-kinase}

Ins $(1,3,4,5,6) \mathrm{P}_{2} 2$-kinase catalyzes the final step in the synthesis of inositol hexakisphosphate from Ins $(1,3,4) \mathrm{P}_{3}$, and ultimately from Ins $(1,4,5) \mathrm{P}_{3}[71]$. The human 2kinase contains an FXFP motif, but does not contain a Ddomain (Table 1). We did not identify an optimal sequence for MAPK phosphorylation.

\section{Inositol monophosphatase}

Inositol monophosphatase is a $\mathrm{Mg}^{2+}$-dependent enzyme that catalyzes the hydrolysis of Ins $1 \mathrm{P}$, Ins3P and Ins4P, as well as several related compounds, but does not hydrolyze Ins2P [74-78]. Inositol monophosphatase has received significant attention as a potential site of action for lithium in the treatment of bipolar disorder. However, recent studies have identified a number of other lithium targets, as well [79].

Three forms of inositol monophosphatase have been identified: A1 (IMPA1), A2 (IMPA2) and A3 (IMPA3). Of these three forms, only inositol monophosphatase A1 contains an identifiable D-domain (Tables 6 and 8). The human and mouse sequences differ by two amino acids in this region resulting in an alternative pair of D-domains in the mouse isoform (and 261 RIAKEIEI and ${ }^{261}$ RIAKEIEIIPL) and a single D-domain in the human isoform ( ${ }^{261}$ RIAKEIQVIPL). We did not find an optimal sequence for MAPK-catalyzed phosphorylation or an FXFP motif in 
any of the human or mouse inositol monophosphatase isozymes.

\section{I-phosphatase}

Inositol polyphosphate 1-phosphatase is a $\mathrm{Mg}^{2+}$-dependent enzyme that hydrolyzes $\operatorname{Ins}(1,4) \mathrm{P}_{2}$ and $\operatorname{Ins}(1,3,4) \mathrm{P}_{3}$, and is inhibited by lithium [76,80-82]. Similar to inositol monophosphatase, the 1-phosphatase has received attention as a site of therapeutic action for lithium in the treatment of bipolar disorder [83]. Notably, the human (Table 6), but not the mouse (Table 9), 1-phosphatase contains a D-domain. Neither the human nor mouse enzyme contains an FXFP motif or an optimal sequence for MAPK phosphorylation.

\section{3-phosphatase}

Myotubularin, which was originally identified as a candidate gene mutated in X-linked myotubular myopathy [84], has been shown to possess PtdIns3P 3-phosphatase activity $[85,86]$. A number of myotubularin-related (MTMR) proteins have also been identified $[87,88]$. Myotubularin (also called MTM1), MTMR1, MTMR2, MTMR3, and MTMR6 possess PtdInd(3)P 3-phosphatase activity [89]. In addition to their PtdIns3P 3-phosphatase activity, myotubularin, [90], MTMR2 [91], MTMR3 [92], and MTMR6 [90] also possess PtdIns(3,5) $\mathrm{P}_{2}$ 3-phosphatase activity; however, it should be noted that Kim et al. [89] reported that myotubularin and MTMR2 do not hydrolyze PtdIns $(3,5)_{2}$. Additionally, myotubularin and MTMR2 have been shown to hydrolyze Ins $(1,3) \mathrm{P}_{2}[89]$.

When we analyzed the human (Table 7) and mouse (Table 9) myotubularin protein sequences, we did not find either an FXFP or D-domain sequence. However, the human sequence does contain two optimal MAPK phosphorylation sequences not present in the mouse sequence. We identified a conserved $\mathrm{D}$-domain in the human (Table 6) and mouse (Table 8) MTMR1 protein, but did not find an optimal sequence for MAPK phosphorylation or FXFP motif in either protein. Neither the human (Table 7) nor the mouse (Table 9) MTMR2 has an optimal sequence for MAPK phosphorylation, a Ddoman, or an FXFP motif. Although the human (Table 7) and mouse (Table 9) MTMR3 and MTMR6 each contain a sequence fitting the optimal sequence for MAPK phosphorylation, they do not contain an identifiable Ddomain or FXFP motif.

PTEN (phosphatase and tensin homologue deleted on chromosome 10) is a PtdIns $(3,4,5) \mathrm{P}_{3} 3$-phosphatase [93], as well as $\operatorname{Ins}(1,3,4,5) \mathrm{P}_{4}$ 3-phosphatase [93] and Ins $(1,3,4,5,6) \mathrm{P}_{5} 3$-phosphatase [94]. The human (Table 6) and mouse (Table 8) PTEN sequences contain a conserved FXFP sequence, but no identifiable D-domain or optimal MAPK phosphorylation sequence.

\section{4-phosphatase}

Two forms (Types I and II) of inositol polyphosphate 4phosphatase have been identified [95-97]. These enzymes cleave the 4-phosphate from Ins $(1,3,4) \mathrm{P}_{2}$, Ins $(3,4) \mathrm{P}_{2}$, and PtdIns $(3,4) \mathrm{P}_{2}$. The Type I 4-phosphatase has been reported to localize to endosomes, where it plays an important role in the generation of PtdIns3P [98]. In growth factor-stimulated cells the Type I 4-phosphatase also localizes to plasma membrane ruffles, where it hydrolyzes PtdIns $(3,4,) \mathrm{P}_{2}$, thereby regulating the association of PtdIns $(3,4) \mathrm{P}_{2}$-binindg proteins with the plasma membrane [98]. We identified a conserved D-domain in human (Table 6) and mouse (Table 8) Type I 4-phosphatase. However, we did not identify an optimal phosphorylation sequence or an FXFP motif in this isoform. In contrast, we did not identify a D-domain in the human Type II 4-phosphatase (Table 7), although it does contain a consensus MAPK phosphorylation site. Human Type II 4-phosphatase also does not contain an FXFP motif.

The Sac phosphatase domain, a region of sequence homology found in several yeast, plant and animal proteins, can hydrolyze the 3-, 4-, or 5-position phosphate from PIs, although vicinal phosphate groups are resistant to hydrolysis $[99,100]$; thus, PtdIns3P, PtdIns4P and PtdIns $(3,5) \mathrm{P}_{2}$ are substrates, whereas PtdIns $(4,5) \mathrm{P}_{2}$ is not. The PtdIns4P phosphatase activity, but not PtdIns3P or PtdIns $(3,5) \mathrm{P}_{2}$ phosphatase activities, of mammalian Sac1 complements phenotypic defects observed in yeast having deletions of Sac1p [101], indicating that the 4-phosphatase activity of these proteins is the most important in vivo. The human (Table 6) and mouse (Table 8) Sac1 proteins each contain five identifiable D-domains. Two of these D-domains are overlapping sequences (345KNMRWDRLSI and ${ }^{348}$ RWDRLSILL) and two are an alternative pair of D-domains (517RDWKFLAL and ${ }^{517}$ RDWKFLALPI). Neither the human nor mouse protein contains an optimal phosphorylation site for MAPKs or an FXFP motif.

\section{5-phosphatase}

The inositol polyphosphate 5-phosphatases are commonly classified on the basis of their substrate specificities $[27,50]$. In this system of classification, the Group I enzymes hydrolyze the water-soluble compounds Ins $(1,4,5) \mathrm{P}_{3}$ and $\operatorname{Ins}(1,3,4,5) \mathrm{P}_{4}$; the Group II enzymes hydrolyze both water-soluble and lipid substrates (e.g., $\operatorname{PtdIns}(4,5,) \mathrm{P}_{2}$ and PtdIns $\left.(3,4,5) \mathrm{P}_{3}\right)$; the Group III enzymes hydrolyze the 3-phosphate-containing compounds, Ins $(1,3,4,5) \mathrm{P}_{4}$ and PtdIns $(3,4,5) \mathrm{P}_{3}$; and, the single Group IV enzyme hydrolyzes only the lipid substrates PtdIns $(3,4,5) \mathrm{P}_{3}$ and PtdIns $(4,5) \mathrm{P}_{2}[27,102]$. Although we have used this classification system, we note that recent studies have demonstrated that the substrate specificities of several of the identified 5-phosphatases do not fit into 
Table 8: Phosphatases (mouse) that have an FXFP motif and/or D-domain sequence. The number of potential MAPK phosphorylation sites, sequences fitting the optimal MAPK phosphorylation consensus sequence of PX(S/T)P, and FXFP motifs and D-domain sequences in phosphatases that use phosphatidylinositols or inositols as substrates are listed in the table; all sequences are for mouse proteins.

\begin{tabular}{lcccc}
\hline Isozyme & $\begin{array}{c}\text { GenBank } \\
\text { Accession \# }\end{array}$ & $\begin{array}{c}\text { \# amino } \\
\text { acids }\end{array}$ & \# (S/T)P sites & $\begin{array}{c}\text { Site(s) with the } \\
\text { consensus PX(S/ } \\
\text { T)P sequence }\end{array}$ \\
\hline
\end{tabular}

\begin{tabular}{|c|c|c|c|c|c|c|}
\hline \multicolumn{7}{|c|}{ monophosphatase } \\
\hline inositol monophosphatase Al & $\underline{055023}$ & 277 & 2 & none & none & $\begin{array}{l}\text { 26IRIAKEIEI } \\
\text { 26IRIAKEIEIIPL }\end{array}$ \\
\hline \multicolumn{7}{|c|}{ 3-phosphatase } \\
\hline Myotubularin-related protein I; MTMR I & NP 058681 & 669 & 4 & none & none & ${ }^{181}$ KDMRNLRL \\
\hline $\mathrm{PI}(3,4,5) \mathrm{P}_{3}$ 3-phosphatase, PTEN & $\underline{008586}$ & 403 & 2 & none & ${ }^{24 I}$ FEFP & none \\
\hline \multicolumn{7}{|c|}{ 4-phosphatase } \\
\hline Inositol polyphosphate 4-phosphatase, Type la & NP 084542 & 939 & 7 & none & none & ${ }^{147}$ RHHRLHLTL \\
\hline SACI poly-phosphatidylinositol phosphatase & CAC20672 & 587 & 3 & none & none & $\begin{array}{c}{ }^{345} \mathrm{KNMRWDRLSI} \\
\text { 348RWDRLSILL } \\
\text { 461RTGKRTQLGL } \\
\text { 517RDWKFLAL } \\
517 \text { RDWKFLALPI }\end{array}$ \\
\hline \multicolumn{7}{|c|}{ 5-phosphatase } \\
\hline \multicolumn{7}{|l|}{ Group II } \\
\hline Inositol polyphosphate 5-phosphatase OCRL & NP 796189 & 900 & 2 & none & none & ${ }^{445 K L L K F D G L N I ~}$ \\
\hline $\begin{array}{l}\text { Synaptojanin } 2 \text { (synaptic inositol 1,4,5- } \\
\text { trisphosphate 5-phosphatase } 2 \text { ) }\end{array}$ & Q9D2G5 & 1434 & 15 & 987PVSP & none & 617RSHRYILL \\
\hline Sac-domain-containing inositol phosphatase 3 & NP 598760 & 907 & 5 & none & none & ${ }^{663}$ KFHRWEEEIDI \\
\hline $\begin{array}{l}\text { Inositol polyphosphate 5-phosphatase, } 75 \text { kDa; } \\
\text { Inositol polyphosphate 5-phosphatase B } \\
\text { Groub III }\end{array}$ & NP 032411 & 993 & 5 & none & none & $\begin{array}{l}\text { 31RQSRLLGL } \\
\text { 420KFVRLVGIML }\end{array}$ \\
\hline $\begin{array}{l}\text { Inositol polyphosphate 5-phosphatase, I45 kDa; } \\
\text { inositol polyphosphate 5-phosphatase D; SH2- } \\
\text { containing inositol 5'-phosphatase I; SHIPI }\end{array}$ & NP 034696 & 1191 & 12 & $\begin{array}{l}\text { 962PPTP } \\
\text { 970PLSP }\end{array}$ & none & 352KSQKFLNKLVI \\
\hline \multicolumn{7}{|l|}{ Group IV } \\
\hline $\begin{array}{l}\mathrm{PI} \text { polyphosphate 5-phosphatase type IV; } \\
\text { Inositol polyphosphate 5-phosphatase E }\end{array}$ & Q9 & 647 & 7 & 243PRSP & none & $\begin{array}{l}{ }^{83} \text { KLERTLSL } \\
{ }^{599} \text { RPGRDNIPL } \\
\text { 611KFDRELYL } \\
611 \text { KFDRELYLIGI }\end{array}$ \\
\hline
\end{tabular}

this simple system $[103,104]$. For example, Schmid et al [103] have shown that there are significant differences in the substrate specificities of several "Type II" 5-phosphatases: synaptojannin 1 , synaptojanin 2 , the gene product responsible for Lowe's oculocerebrorenal syndrome (OCRL), skeletal muscle and kidney enriched phosphatase (SKIP), and INPP5B. Additionally, it should be noted that the in vitro and in vivo specificities of these enzymes may differ.

We did not identify a D-domain, FXFP motif or optimal MAPK phosphorylation sequence in either the human (Table 7) or mouse (Table 9) Type I 5-phosphatase. Sev- eral of the Group II 5-phosphatases (Tables 6 and 8) contain an identifiable D-domain. OCRL is the gene responsible for occulocerebrorenal dystrophy or Lowe's syndrome, when mutated [27]. Both the human (Table 6) and mouse (Table 8 ) OCRL proteins contain a D-domain, but do not contain an FXFP motif or an optimal sequence for MAPK phosphorylation. Synaptojanin 1 and synaptojanin 2 are neuronal proteins that play a role in synaptic vesicle trafficking. They contain both a 5-phosphatase domain and a Sac phosphatase domain [99]. The 5-phosphatase domain is responsible for the reported PtdIns $(4,5) \mathrm{P}_{2}$-hydrolyzing activity of synaptojanins, while the Sac domain of synaptojanins accounts for their 
ability to also hydrolyze other PIs, such as the PtdIns4P product generated by the action of its 5-phosphatase domain [105]. Both synaptojanin 1 and 2 contain optimal phosphorylation sites for MAPKs. However, only synaptojanin 2 contains a D-domain, which is conserved in the human (Table 6) and mouse (Table 8 ) proteins. The synaptojanin sequences that we searched do not contain an FXFP motif. The human (Table 6) and mouse (Table 8) 75-kDa inositol polyphosphate 5-phosphatases (inositol polyphosphate 5-phosphatase B) contain two conserved D-domains, but are devoid of an FXFP motif and an optimal sequence for MAPK phosphorylation.

The Group III SH2-containing inositol 5'-phosphatase 1 (SHIP1) is a hematopoietic-specific enzyme that hydrolyzes both PtdIns $(3,4,5)_{3}$ and Ins $(1,3,4,5) \mathrm{P}_{4}$ [106]. In addition, SHIP1 is able to hydrolyze the 4-phosphate from PtdIns $(4,5)$ in vitro, thereby generating PtdIns5P [107]. The human (Table 6) and mouse (Table 8) SHIP1 contain an identifiable D-domain. The human SHIP1 contains four optimal MAPK phosphorylation sequences; corresponding sequences for two of these are present in the mouse protein, whereas two are unique to the human protein. SHIP1 does not contain a sequence conforming to an FXFP motif. The distribution of SHIP2 is more ubiquitous than is that of SHIP1 [106]. The human SHIP2 is devoid of a D-domain or an FXFP motif (Table 7). It does contain four sequences that fit the optimal phosphorylation sequence for a MAPK. The human (Table 6) and mouse (Table 8) Group IV 5-phosphatase contain a conserved optimal sequence (PRSP) for MAPK phosphorylation; the human protein contains an additional optimal sequence of MAPK phosphorylation ( ${ }^{55}$ PATP). Both the human and mouse Group IV 5-phosphatase contain an alternative pair of D-domains, as well as two other Ddomains; neither contains an FXFP motif.

\section{Additional sequence analyses}

We examined each of the D-domains that we identified to determine if it overlaps with a KIM [14] or fits the MAPKdocking site consensus sequence defined by Bardwell and colleagues $[15,16]$. We found only one instance of overlap with a KIM: in the human PI 4-kinase $\alpha$, the sequence ${ }^{12}$ LDERRRDAVIALGI not only contains the alternative pair of D-domains that we identified (Table 1), but also contains a KIM. Examination of the sequences found in Tables 1, 3, 6, and 8 revealed that, in several instances, the D-domain sequence fits the MAPK-docking sequence of Bardwell and colleagues. It should be noted that in several proteins we identified, but did not catalog, one or more sequence that conformed to the MAPK-docking motif of Bardwell and colleagues but did not conform to the more restrictive sequence that we used for a D-domain.
Finally, we also analyzed the sequences of PtdIns synthase (CDP-1,2-diacyl-sn-glycerol:myo-inositol 3-phosphatidyltransferase) isozymes, which catalyze the production of PtdIns from cytidine diphosphodiacylglycerol and myoinositol. We did not identify either an FXFP or a Ddomain sequence in human or mouse PtdIns synthase sequences (GenBank:NP 006310, NP 665695, and NP 620093; data not shown). Further, we identified a MAPK phosphorylation site only in the human isoform 2. These results indicate that the isozymes that catalyze PtdIns synthesis are not likely to be directly regulated by MAPK; however, they do not rule out the possibility that MAPKs may control PtdIns synthesis via an effect on myoinositol (e.g., via an effect on inositol monophosphatase A1) or cytidine diphosphodiacylglycerol levels.

\section{Conclusion}

We found a high degree of conservation of D-domain sequence and location in human and mouse proteins. Notable exceptions were PI 3-kinase C2- $\gamma$, PI 4-kinase type II $\beta$, and inositol polyphosphate 1-phosphatase. For each of these proteins, either the human or mouse protein contained one or more D-domains that were not found in the other, with the differences in PI 3-kinase C2- $\gamma$ being the most striking.

Other than within subtypes of an isozyme, we found no evidence of sequence conservation of D-domains in enzymes that metabolize PIs and IPs. That is, the primary sequences of the $\mathrm{D}$-domains that we found were quite variable. This indicates that, both within a family and across families of these enzymes, there may be specificity for binding interactions with MAPKs. Detailed studies examining the relative specificities of each of these proteins for individual MAPKs, if they indeed bind MAPKs, and the contribution of individual amino acids within these sequences to MAPK binding, will provide important information for the development of tools aimed at modifying the integration of MAPK and signaling via PIs and IPs.

When D-domains were found in more than one location in a protein, each D-domain had a unique sequence. This is noted because it is not a universal property of proteinprotein interaction domains when present in multiples in a protein- e.g., an $\mathrm{SH}_{2}$-binding motif is commonly present in multiple copies in docking proteins [108]. Within a protein, it is possible that each $\mathrm{D}$-domain binds a unique MAPK, or set of MAPKs, allowing for interaction with more than one MAPK signaling pathway, and, thus, the regulation of the metabolism of a particular PI/IP by various combinations of stimuli, or the formation of differing combinations of signaling complexes allowing for the generation of various downstream signals. Further, it is also possible that each interaction is independently regulated. Therefore, it is reasonable to think that these D- 
Table 9: Phosphatases (mouse) that do not have an FXFP motif and/or D-domain sequence. Phosphatases that use phosphatidylinositols or inositols as substrates and do not contain an FXFP or D-domain sequence are listed in the table; all sequences are for mouse proteins. The number of potential MAPK phosphorylation sites and sequences fitting the optimal MAPK phosphorylation in these kinases are also identified.

\begin{tabular}{|c|c|c|c|c|}
\hline Isozyme & GenBank Accession \# & \# amino acids & \# (S/T)P sites & $\begin{array}{l}\text { Site(s) with the consensus } \\
\mathrm{PX}(\mathrm{S} / \mathrm{T}) \mathrm{P} \text { sequence }\end{array}$ \\
\hline inositol monophosphatase $\mathrm{A} 2$ & NP 444491 & 290 & I & none \\
\hline inositol monophosphatase $\mathrm{A} 3$ & NP 808398 & 356 & 2 & none \\
\hline Inositol polyphosphate I-phosphatase & P49442 & 396 & 2 & none \\
\hline Myotubularin; MTMI & Q9Z2C5 & 603 & I & none \\
\hline Myotubularin-related protein 2; MTMR2; & Q9Z2DI (AAH63050) & 643 & 4 & none \\
\hline Myotubularin-related protein 3; MTMR3 & CAI35I86 & 1159 & 7 & 582PSTP \\
\hline Myotubularin-related protein 6; MTMR6 & NP 659092 & 617 & 3 & 555PETP \\
\hline Inositol polyphosphate 4-phosphatase, Type lb (variant) & NP 766559 & 679 & 3 & none \\
\hline Inositol 1,4,5-trisphosphate 5-phosphatase, Type I & $\overline{\mathrm{AAH} 56341}$ & 412 & 2 & none \\
\hline $\begin{array}{c}\text { Synaptojanin I (synaptic inositol I,4,5-trisphosphate 5- } \\
\text { phosphatase I) }\end{array}$ & $\mathrm{Q} 8 \mathrm{CHC} 4$ & 1574 & 19 & $\begin{array}{l}1145 \text { PPSP } \\
\text { 1158PKSP } \\
\text { 1443PNSP }\end{array}$ \\
\hline $\mathrm{PI}(4,5) \mathrm{P}_{2}$ 5-phosphatase A; PIB5PA; PIPP & NP 766027 & 1003 & 31 & $\begin{array}{l}197 \mathrm{PQSP} \\
\text { 200PSSP } \\
\text { 346 PRSP }\end{array}$ \\
\hline $\begin{array}{c}\text { Skeletal muscle and kidney enriched inositol phosphatase } \\
\text { isoform I; SKIP I }\end{array}$ & Q8C5L6 & 468 & 5 & none \\
\hline $\begin{array}{l}\text { Phospholipid-inositol phosphatase; PTEN-like phosphatase; } \\
\text { PLIP }\end{array}$ & NP 079852 & 261 & 3 & none \\
\hline
\end{tabular}

domains do not simply serve to amplify signaling through a single signaling pathway, but, instead, allow for the integration of multiple MAPK pathways with the metabolism of a specific PI or IP.

The frequency of occurrence of an identifiable FXFP motif in the enzymes that we analyzed was significantly less than that of a D-domain. There were only five enzymes in which we found a motif conforming to the sequence FXFP; four of these were in kinases (PI 3-kinase $\delta$, PI 4kinase $\alpha, \operatorname{Ins}(1,4,5) \mathrm{P}_{3} 3$-kinase $\mathrm{B}$, and $\operatorname{Ins}(1,3,4,5,6) 2$ kinase) and only a single one was found in a phosphatase (PTEN). It is noteworthy that of all the enzymes that we analyzed, only PI 4-kinase $\alpha$ and Ins $(1,4,5) \mathrm{P}_{3}$ 3-kinase B contain both a D-domain and an FXFP sequence. Finally, we found several sequences fitting an FXF motif (data not shown). As noted in the Introduction, the FXF sequence has been reported to be sufficient for MAPK binding, indicating that these sites may also bind MAPKs.

At this time, we can only speculate on the physiologic significance of the presence of MAPK binding domains in enzymes that control the metabolism of PIs and IPs. We have previously shown that phospho-ERK2-dependent phosphorylation of PLC- $\gamma 1$ opposes tyrosine kinasedependent activation of PLC- $\gamma 1$ [25]. Similarly, MAPKs may regulate (either stimulating or inhibiting) the catalytic activity, or specificity, of kinases and phosphatases that are involved in the metabolism of PIs or IPs, and thereby exert regulatory actions on PI- and/or IP-depend- ent signaling pathways. Intriguing possibilities exist when a kinase and phosphatase are present in the same complex and one or both of them bind a MAPK. For example, the p85 subunit of Class I PI 3-kinase has been reported to form a complex with Type I inositol polyphosphate 4phosphatase [109], SHIP1 5-phosphatase [110], and Type IV 5-phosphatase [111]. In these complexes, MAPKs may regulate the relative level or turnover of the substrates and products; for example, by enhancing PI3-kinase activity and associated SHIP1 (or Type IV) 5-phosphatase activity, it would be possible to increase PtdIns $(3,4) \mathrm{P}_{2}$ levels without increasing PtdIns $(3,4,5) \mathrm{P}_{3}$ levels. Other scenarios (e.g., delayed activation kinetics of the associated 5-phosphatase) are also imaginable, resulting in a transient rise in PtdIns $(3,4,5) \mathrm{P}_{3}$ with a delayed elevation in PtdIns $(3,4,) \mathrm{P}_{2}$ levels. Similarly, complexes of the Type I inositol polyphosphate 4-phosphatase and PI 3-kinase could produce locally elevated levels of PtdIns3P, without elevating PtdIns $(3,4) \mathrm{P}_{2}$ levels, or elevate PtdIns $(3,4) \mathrm{P}_{2}$ and, with a delay, PtdIns3P. It is also possible that the interaction between a MAPK and a PI/IP kinase or phosphatase may recruit the MAPK to a multimolecular signal transduction complex containing components of pathways that regulate the activity of the MAPK (e.g., binding of a MAPK to PI 3-kinase may act to recruit the MAPK to a growth factor signaling complex containing Ras and a MAPK kinase) or target the MAPK to a particular subcellular localization (e.g., binding to Type I inositol polyphosphate 4-phosphatase may act to target the MAPK to endosomes). 
It should be noted that a protein can serve as a MAPK substrate without directly binding the MAPK: c-Jun-bound proteins that lack a JNK binding site can be phosphorylated by JNK [112]. Thus, our inability to identify a MAPK binding site in a protein does not preclude it from being a MAPK substrate. For example, the MAPK optimal phosphorylation site identified in Type II $\alpha$ PIPK could be phosphorylated by a MAPK bound to Type I $\alpha$ PIPK, which has been shown to co-immunoprecipitate with Type II $\alpha$ PIPK [113]. Similarly, although we did not identify a Ddomain or FXFP motif in the 3-phosphatase myotubularin, it may be a MAPK substrate when bound to the 3phosphatase adaptor protein (3-PAP) subunit [114], which has four recognizable D-domains (data not shown). In fact, human myotubularin does contain two optimal MAPK phosphorylation sequences (Table 7), indicating that it may be a MAPK substrate.

PI 3-kinase, Ins $(1,4,5) \mathrm{P}_{3}$ 3-kinase $\mathrm{B}, \mathrm{SHIP1}$ and PTEN have each been proposed to regulate MAPK signaling. In the case of PI 3-kinase, several studies have been published showing that wortmannin and/or LY-294002, which are inhibitors of PI 3-kinase catalytic activity, block the activation of MAPKs by various stimuli. However, to our knowledge, a direct interaction between a PI 3-kinase and a MAPK has not been demonstrated, and the mechanisms underlying the apparent PI 3-kinase-dependent regulation of MAPKs remain speculative. In the case of PI 3kinase $\gamma$, the effect could be mediated by MEK-1, a MAPK kinase which has been shown to be an in vitro substrate of PI 3-kinase $\gamma$ [115]. Wen et al [65] have shown that ERK1/ 2 activation in response to suboptimal stimulation of thymocytes is dependent on $\operatorname{Ins}(1,4,5) \mathrm{P}_{3} 3$-kinase $\mathrm{B}$; they propose a model in which $\operatorname{Ins}(1,4,5) \mathrm{P}_{3}$ 3-kinase $\mathrm{B}$ dependent production of $\operatorname{Ins}(1,3,4,5) \mathrm{P}_{4}$ acts to sequester an Ins $(1,3,4,5) \mathrm{P}_{4}$-binding GTPase-activating protein 1 [116], promoting Ras-dependent activation of ERK1/2. SHIP1, which contains an identifiable D-domain, but no FXFP motif, has been shown to be a negative regulator of JNK activation in B cells [117], ERK1/2 activation in the erythropoietin-dependent cell lineAS-E2 [118], and MAPK (ERK1/2, JNK and p38) activation in RAW264.7 macrophages [119]. In the latter case, the action was shown to be independent of the SHIP1 5-phosphatase activity

[119].

Interestingly, SHIP2, which does not have an identifiable D-domain or FXFP motif, has been reported to not exert an effect on cellular MAPKs $[120,121]$. PTEN, which does not contain a D-domain sequence but does contain an FXFP motif, has been reported to inhibit insulin-stimulated ERK1/2 activation in MCF-7 epithelial breast cancer cells $[122,123]$. Weng et al. [122] concluded that the effect of PTEN is the result of PTEN-dependent dephosphorylation of the insulin receptor substrate 1 , and consequent coupling to ERK1/2 activation. In contrast to the studies of Eng and colleagues, Tang et al. [121] reported that short interfering RNA-induced reductions of PTEN expression in 3T3-L1 adipocytes did not affect insulin-dependent signaling to ERK1/2.

In conclusion, there appear to be a plethora of potential sites of crosstalk between MAPK signaling pathways and the enzymes controlling cellular PIs and IPs, and, thus, the signaling pathways that are regulated by the levels of these intracellular signals. We hope that the identification of these sites of signal integration will initiate a series of studies aimed at determining whether these interactions occur in vivo and the physiologic relevance of each to cellular responding.

\section{Competing interests}

The author(s) declare that they have no competing interests

\section{Authors' contributions}

Kevin Caldwell was involved in the conception of these studies, collecting and analyzing sequence data, and drafting and revising the manuscript. Marcos Sosa was responsible for collecting and analyzing sequence data, as well as reviewing the manuscript. Colin Buckley was involved in the conception of these studies, collecting and analyzing sequence data, and reviewing the manuscript. All authors have given final approval of the manuscript.

\section{Acknowledgements}

This work was supported, in part, by Dedicated Health Research Funds of the University of New Mexico School of Medicine and National Institutes of Health grant MH076I26

\section{References}

I. Clark-Lewis I, Sanghera JS, Pelech SL: Definition of a consensus sequence for peptide substrate recognition by $\mathrm{p} 44 \mathrm{mpk}$, the meiosis-activated myelin basic protein kinase. J Biol Chem 1991, 266: $15180-15184$

2. Songyang Z, Lu KP, Kwon YT, Tsai L-H, Filhol O, Cochet C, Brickey DA, Soderling TR, Bartleson C, Graves DJ, DeMaggio AJ, Hoekstra MF, Blenis J, Hunter T, Cantley LC: A structural basis for substrate specificities of protein Ser/Thr kinases: primary sequence preference of casein kinases I and II, NIMA, phosphorylase kinase, calmodulin-dependent kinase II, CDK5, and Erk I. Mol Cell Biol 1996, I6:6486-6493.

3. Gonzalez FA, Raden DL, Davis RJ: Identification of substrate recognition determinants for human ERKI and ERK2 protein kinases. J Biol Chem I991, 266:22159-22163.

4. Jacobs D, Glossip D, Xing H, Muslin AJ, Kornfeld K: Multiple docking sites on substrate proteins form a modular system that mediates recognition by ERK MAP kinase. Genes Dev 1999 , I3:163-175.

5. Yang S-H, Whitmarsh AJ, Davis RJ, Sharrocks AD: Differential targeting of MAP kinases to the ETS-domain transcription factor Elk-I. EMBO J 1998, I 7:1740-1749.

6. Yang S-H, Galanis A, Sharrocks AD: The Elk-I ETS-Domain Transcription Factor Contains a Mitogen-Activated Protein Kinase Targeting Motif. Mol Cell Biol 1999, I 9:4028-4038.

7. Seidel J, Graves BJ: An ERK2 docking site in the Pointed domain distinguishes a subset of ETS transcription factors. Genes Dev 2002, 1 6:127-137. 
8. Adler V, Franklinm CC, Kraft AS: Phorbol esters stimulate the phosphorylation of c-Jun but not v-Jun: regulation by the $\mathbf{N}$ terminal $\delta$ domain. Proc Natl Acad Sci USA 1992, 89:534I-5345.

9. Hibi M, Lin A, Smeal T, Minden A, Karin M: Identification of an oncoprotein- and UV-responsive protein kinase that binds and potentiates the c-Jun activation domain. Genes De 1993 7:2135-2148.

10. Gupta S, Campbell D, Derijard B, Davis RJ: Transcription factor ATF2 regulation by the JNK signal transduction pathway. Science 1995, 267:389-393.

II. Livingstone C, Patel G, Jones N: ATF-2 contains a phosphorylation-dependent transcriptional activation domain. EMBO J 1995, I 4: I785-I797.

12. Yang S-H, Yates PR, Whitmarsh AJ, Davis RJ, Sharrocks AD: The ElkI ETS-Domain Transcription Factor Contains a MitogenActivated Protein Kinase Targeting Motif. Mol Cell Biol 1998, 18:710-720.

13. Pulido R, Zúñiga A, Ullrich A: PTP-SL and STEP protein tyrosine phosphatases regulate the activation of the extracellular signal-regulated kinases ERK I and ERK2 by association through a kinase interaction motif. $E M B O$ J 1998, 24:7337-7350.

14. MacKenzie SJ, Baillie GS, McPhee I, Bolger GB, Houslay MD: ERK2 mitogen-activated protein kinase binding, phosphorylation, and regulation of the PDE4D cAMP-specific phosphodiesterases. The involvement of $\mathrm{COOH}$-terminal docking sites and $\mathrm{NH}_{2}$-terminal UCR regions. J Biol Chem 2000, 275:16609-166I7.

15. Bardwell AJ, Flatauer LJ, Matsukuma K, Thorner J, Bardwell L: A conserved docking site in MEKs mediates high-affinity binding to MAP kinases and cooperates with a scaffold protein to enhance signal transmission. J Biol Chem 200I, 276: I0374- 10386.

16. Bardwell AJ, Abdollahi M, Bardwell L: Docking sites on mitogenactivated protein kinase (MAPK) kinases, MPK phosphatases and the Elk-I transcription factor compete for MAPK binding and are crucial for enzymatic activity. Biochem J 2003 , 370: $1077-1085$

17. Ho DT, Bardwell J, Abdollahi M, Bardwell L: A docking site in MKK4 mediates high affinity binding to JNK MAPKs and competes with similar docking sites in nJNK substrates. J Biol Chem 2003, 278:32662-32672.

18. Fantz DA, Jacobs D, Glossip D, Kornfeld K: Docking sites on substrate proteins direct extracellular signal-regulated kinase to phosphorylate specific residues. I Biol Chem 200I, 276:27256-27265.

19. Tanoue T, Nishida E: Molecular recognitions in the MAP kinase cascade. Cell Signal 2003, 15:455-462.

20. Biondi RM, Nebreda AR: Signaling specificity of Ser/The protein kinases through docking-site-mediated interactions. Biocehm J 2003, 372:1-13.

21. Barsyte-Lovejoy D, Galanis A, Sharrocks AD: Specificity determinants in MAPK signaling to transcription factors. J Biol Chem 2002, 277:9896-9903.

22. Galanis A, Yang S-H, Sharrocks AD: Selective targeting of MAPKs to the ETS domain transcription factor SAP-I. J Biol Chem 200I, 276:965-973.

23. Smith JA, Potet-Smith CE, Malarkey K, Sturgill T: Identification of an extracellular signal-regulated kinase (ERK) docking site in ribosomal $\mathbf{5 6}$ kinase, a sequence critical for activation by ERK in vivo. J Biol Chem 1999, 274:2893-2898.

24. Vinciguerra M, Vivacqua A, Fasanella G, Gallo A, Cuozzo C, Morano A, Maggiolini M, Musti AM: Differential phosphorylation of c-Jun and JunD in response to the epidermal growth factor is determined by the structure of MAPK targeting sequences. J Biol Chem 2004, 279:9634-964I.

25. Buckley CT, Sekiya F, Kim YJ, Rhee SG, Caldwell KK: Identification of phospholipase $\mathbf{C}-\gamma \mathbf{I}$ as a mitogen-activated protein kinase substrate. J Biol Chem 2004, 279:4 1807-4I8I4

26. Buckley CT, Caldwell KK: Fear conditioning is associated with altered integration of PLC and ERK signaling in the hippocampus. Pharmacol Biochem Behav 2004, 79:633-640.

27. Majerus PW, Kisseleva MV, Norris FA: The role of phosphatases in inositol signaling reactions. J Biol Chem 1999, 274:10669-10672.

28. Toker A: Phosphoinositides and signal transduction. Cell MolLife Sci 2002, 59:761-779.

29. Parker PJ: The ubiquitous phosphoinositides. Biochem Soc Trans 2004, 32:893-898.
30. Irvine RF, Schell MJ: Back in the water: the return of the inositol phosphates. Nat Rev Mol Cell Biol 200I, 2:327-338.

31. Rhee SG: of phosphoinositide-specific phospholipase C. Annu Rev Biochem 200I, 70:28I-312.

32. Cantley LC: The phosphoinositide 3-kinase pathway. Science 2002, 296:1655-1657.

33. De Matteis MA, Godi A, Corda D: Phosphoinositides and the Golgi complex. Curr Opin Cell Biol 2002, 1 4:434-447.

34. Janmey PA, Lindberg U: Cytoskeletal regulation: rich in lipids. Nat Rev Mol Cell Biol 2004, 5:658-666.

35. Niggli V: Regulation of protein activities by phosphoinositide phosphates. Annu Rev Cell Dev Biol 2005, 21 :57-79.

36. Shears SB: How versatile are inositol phosphate kinases? Biochem J 2004, 377:265-280.

37. Irvine RF: Inositide evolution- toward turtle domination? Physiol 2005, 566:295-300.

38. Chan TO, Rittenhouse SE, Tsichlis PN: AKT/PKB and other D3 phosphoinositide-regulated kinases: Kinase activation by phosphoinositide-dependent phosphorylation. Annu Rev Biochem 1999, 68:965-1014.

39. Deane JA, Fruman DA: Phosphoinositide 3-kinase: Diverse roles in immune cell activation. Annu Rev Immunol 2004, 22:563-598.

40. Whitman M, Downes CP, Keeler M, Keller T, Cantley L: Type I phosphatidylinositol kinase makes a novel inositol phospholipid, phosphatidylinositol-3-phosphate. Nature 1988 , 332:644-646.

4I. Carpenter CL, Duckworth BC, Auger KR, Cohen B, Schaffhausen BS, Cantley LC: Purification and characterization of phosphoinositide 3-kinase from rat liver. I Biol Chem 1990, 265: |9704-| $97 \mid$ I.

42. Stephens LR, Hughes KT, Irvine RF: Pathway of phosphatidylinositol $(3,4,5)$-trisphosphate synthesis in activated neutrophils. Nature 1991, 35 I:33-39.

43. Domin J, Pages F, Volinia S, Rittenhouse SE, Zvelebil MJ, Stein RC, Waterfield MD: Cloning of a human phosphoinositide 3-kinase with a $C 2$ domain that displays reduced sensitivity to the inhibitor wortmannin. Biochem J 1997, 326: I39-|47.

44. Volinia S, Dhand R, Vanhaesebroeck B, MacDougall LK, Stein R, Zvelebil MJ, Domin J, Panaretou C, Waterfield MD: A human phosphatidylinositol 3-kinase complex related to the yeast Vps34p-Vps I5p protein sorting system. EMBO J 1995, I 4:3339-3348.

45. Heilmeyer LMG Jr, Verb G Jr, Verb G, Kakuk A, Szivák I: Mammalian phosphatidylinositol 4-kinases. IUBMB Life 2003, 55:59-65.

46. Berditchevski F, Tolias KF, Wong K, Carpenter CL, Hemler ME: A novel link between integrins, transmembrane-4 superfamily proteins (CD63 and CD8I), and phosphatidylinositol 4kinase. I Biol Chem 1997, 272:2595-2598.

47. Balla A, Tuymetova G, Barshishat M, Geiszt M, Balla T: Characterization of type II phosphatidylinositol 4-kinase isoforms reveals association of the enzymes with endosomal vesicular compartments. J Biol Chem 2002, 277:2004I-20050.

48. Godi A, Pertile P, Meyers R, Marra P, Di Tullio G, lurisci C, Luini A, Corda D, De Matteis MA: ARF mediates recruitment of Ptdlns4-OH kinase- $\beta$ and stimulates synthesis of $P \operatorname{tdlns}(4,5) P_{2}$ on the Golgi complex. Nat Cell Biol 1999, I:280-287.

49. Gehrmann T, Heilmeyer LM Jr: Phosphatidylinositol 4-kinases. Eur J Biochem 1998, 253:357-370.

50. Zhang $X$, Majerus PW: Phosphatidylinositol signaling reactions. Semin Cell Dev Biol 1998, 9:153-160.

5I. Doughman RL, Firestone AJ, Anderson RA: Phosphatidylinositol phosphate kinases put $\mathbf{P I 4}, \mathbf{5} \mathbf{P}_{\mathbf{2}}$ in its place. J Membrane Biol 2003, 194:77-89.

52. Ishihara $\mathrm{H}$, Shibasaki Y, Kizuki N, Katagiri $\mathrm{H}$, Yazaki Y, Asano T, Oka $Y$ : Cloning of cDNAs encoding two isoforms of 68-kDa type I phosphatidylinositol-4-phosphate 5-kinase. J Biol Chem 1996, 27|:236||-236|4.

53. Loijens JC, Anderson RA: Type I phosphatidylinositol-4-phosphate 5-kinases are distinct members of this novel lipid kinase family. I Biol Chem 1996, 27 I:32937-32943.

54. Ishihara H, Shibasaki Y, Kizuki N, Wada T, Yazaki Y, Asano T, Oka Y: Type I phosphatidylinositol-4-phosphate 5-kinases. Cloning of the third isoform and deletion/substitution analysis of members of this novel lipid kinase family. J Biol Chem 1998, 273:874I-8748. 
55. Itoh $T$, ljuin $T$, Takenawa $T$ : A novel phosphatidylinositol-5phosphate 4-kinase (phosphatidylinositol-phosphate kinase $I I \gamma)$ is phosphorylated in the endoplasmic reticulum in response to mitogenic signals. J Biol Chem 1998, 273:20292-20299.

56. Lee SY, Voronov S, Letinic K, Nairn AC, Di Paolo G, De Camilli P: Regulation of the interaction between PIPKI $\gamma$ and talin by proline-directed protein kinases. J Cell Biol 2005, 168:789-799.

57. Dewaste V, Moreau C, De Smedt F, Bex F, De Smedt H, Wuytack F, Missiaen $L$, Erneux $C$ : The three isoenzymes of human inositol1,4,5-trisphosphate 3-kinase show specific intracellular localization but comparable $\mathrm{Ca}^{2+}$ responses on transfection in COS-7 cells. Biochem J 2003, 374:4I-49.

58. Choi KY, Kim HK, Lee SY, Moon KH, Sim SS, Kim JW, Chung HK, Rhee SG: Molecular cloning and expression of a complementary DNA for inositol 1,4,5-trisphosphate 3-kinase. Science 1990, 248:64-66.

59. Vanweyenberg V, Communi D, D'Santos CS, Erneux C: Tissue- and cell-specific expression of $\operatorname{Ins}(1,4,5) P_{3}$ 3-kinase isoenzymes. Biochem J 1995, 306:429-435.

60. Dewaste V, Pouillon V, Moreau C, Shears S, Takazawa K, Erneux C Cloning and expression of a cDNA encoding human inositol I,4,5-trisphosphate 3-kinase C. Biochem J 2000, 352:343-35 I.

61. Dewaste V, Roymans D, Moreau C, Erneux C: Cloning and expression of a full-length cDNA encoding human inositol I,4,5-trisphosphate 3-kinase B. Biochem Biophys Res Commun 2002, 291:400-405.

62. Nalaskowski MM, Bertsch U, Fanick W, Stockebrand MC, Schmale H, Mayr GW: Rat inositol I,4,5-trisphosphate 3-kinase C is enzymatically specialized for basal cellular inositol trisphosphate phosphorylation and shuttles actively between nucleus and cytoplasm. J Biol Chem 2003, 278:19765-19776.

63. Hascakova-Bartova R, Pouillon V, Dewaste V, Moreau C, Jacques C, Banting G, Schurmans S, Erneux C: Identification and subcellular distribution of endogenous $\operatorname{Ins}(1,4,5) P_{3}$ 3-kinase $B$ in mouse tissues. Biochem Biophys Res Commun 2004, 323:920-925.

64. Chamberlain PP, Sandberg ML, Sauer K, Cooke MP, Lesley SA, Spraggon G: Structural insights into enzyme regulation for inositol 1,4,5-trisphosphate 3-kinase B. Biochemistry 2005, 44:14486-14493.

65. Wen BG, Pletcher MT, Warashina M, Choe SH, Ziaee N, Wiltshire T, Sauer K, Cooke MP: Inositol $(1,4,5)$ trisphosphate 3 kinase B controls positive selection of $T$ cells and modulates Erk activity. Proc Natl Acad Sci U S A 2004, I 0 I:5604-5609.

66. Pouillon V, Hascakova-Bartova R, Pajak B, Adam E, Bex F, Dewaste V, Van Lint C, Leo O, Erneux C, Schurmans S: Inositol I,3,4,5-tetrakisphosphate is essential for T lymphocyte development. Nat Immunol 2003, 4: II36-II43.

67. Soriano S, Thomas S, High S, Griffiths G, D'santos C, Cullen P, Banting $\mathrm{G}$ : Membrane association, localization and topology of rat inositol 1,4,5-trisphosphate 3-kinase B: implications for membrane traffic and $\mathrm{Ca}^{2+}$ homoeostasis. Biochem J 1997, 324:579-589.

68. Wilson MP, Majerus PW: Isolation of inositol 1,3,4-trisphosphate 5/6-kinase, cDNA cloning and expression of the recombinant enzyme. J Biol Chem 1996, 27 I: I 1904-II9I0.

69. Yang $X$, Shears SB: Multitasking in signal transduction by a promiscuous human Ins $(3,4,5,6) P_{4}$ I-kinase/Ins $(I, 3,4) P_{3} \quad 5 / 6$ kinase. Biochem / 2000, 35 I:55I-555.

70. Ho MWY, Yang X, Carew MA, Zhang T, Hua L, Kwon Y-U, Chung SK, Adelt S, Vogel G, Riley AM, Potter BVL, Shears SB: Regulation of Ins $(3,4,5,6) P_{4}$ signaling by a reversible kinase/phosphatase. Curr Biol 2002, 1 2:477-482.

7I. Verbsky JW, Chang S-C, Wilson MP, Mochizuki Y, Majerus PW: The pathway for the production of inositol hexakisphosphate in human cells. J Biol Chem 2005, 280:191।-1920.

72. Saiardi A, Nagata E, Luo HR, Sawa A, Luo X, Snowman AM, Snyder $\mathrm{SH}$ : Mammalian inositol polyphosphate multikinase synthesizes inositol 1,4,5-trisphosphate and an inositol pyrophosphate. Proc Natl Acad Sci USA 200I, 98:2306-23II.

73. Chang S-C, Miller AL, Feng Y, Wente SR, Majerus PW: The human homolog of the rat inositol phosphate multikinase is an inositol 1,3,4,6-tetrakisphosphate 5-kinase. J Biol Chem 2002, 277:43836-43843.
74. Eisenberg F Jr: D-Myoinositol I-phosphate as product of cyclization of glucose 6-phosphate and substrate for a specific phosphatase in rat testis. J Biol Chem 1967, 242: I375-1382.

75. Takimoto K, Okada M, Matsuda Y, Nakagawa H: Purification and properties of myo-inositol-I-phosphatase from rat brain. J Biochem (Tokyo) 1985, 98:363-370.

76. Ragan Cl, Watling KJ, Gee NS, Aspley S, Jackson RG, Reid GG, Baker R, Billington DC, Barnaby RJ, Leeson PD: The dephosphorylation of inositol I,4-bisphosphate to inositol in liver and brain involves two distinct $\mathrm{Li}^{+}$-sensitive enzymes and proceeds via inositol 4-phosphate. Biochem J 1988, 249: I43-I48.

77. Gee NS, Ragan Cl, Watling KJ, Aspley S, jackson RG, Reid GG, Gani $D$, Shute JK: The purification and properties of myo-inositol monophosphatase from bovine brain. Biochem J 1988 , 249:883-889.

78. McAllister G, Whiting P, Hammond EA, Knowles MR, Atack JR, Bailey $\mathrm{FJ}$, Maigetter R, Ragan Cl: cDNA cloning of human and rat brain myo-inositol monophosphatase. Expression and characterization of the human recombinant enzyme. Biochem J 1992, 284:749-754.

79. Quiroz JA, Gould TD, Manji HK: Molecular effects of lithium. Mol Interv 2004, 4:259-272.

80. Inhorn RC, Majerus PW: Inositol polyphosphate I-phosphatase from calf brain. Purification and inhibition by $\mathrm{Li}^{+}, \mathrm{Ca}^{2+}$, and $\mathrm{Mn}^{2+}$. J Biol Chem 1987, 262:15946-15952.

8I. Inhorn RC, Majerus PW: Properties of inositol polyphosphate Iphosphatase. J Biol Chem 1988, 263: | 4559- 14565.

82. York JD, Majerus PW: Isolation and heterologous expression of a cDNA encoding bovine inositol polyphosphate I-phosphatase. Proc Natl Acad Sci U S A 1990, 87:9548-9552.

83. Steen VM, Lovlie R, Osher Y, Belmaker RH, Berle JO, Gulbrandsen AK: The polymorphic inositol I-phosphatase gene as a candidate for pharmacogenetic prediction of lithium-responsive manic-depressive illness. Pharmacogenetics 1998, 8:259-268.

84. Laporte J, Hu LJ, Kretz C, Mandel JL, Kioschis P, Coy JF, Klauck SM, Poustka A, Dahl N: A gene mutated in X-linked myotubular myopathy defines a new putative tyrosine phosphatase family conserved in yeast. Nat Genet 1996, I3:175-182.

85. Blondeau F, Laporte J, Bodin S, Superti-Furga G, Payrastre B, Mande $\mathrm{JL}:$ Myotubularin, a phosphatase deficient in myotubular myopathy, acts on phosphatidylinositol 3-kinase and phosphatidylinositol 3-phosphate pathway. Hum Mol Genet 2000, 9:2223-2229

86. Taylor GS, Maehama T, Dixon JE: Myotubularin, a protein tyrosine phosphatase mutated in myotubular myopathy, dephosphorylates the lipid second messenger, phosphatidylinositol 3-phosphate. Proc Natl Acad Sci USA 2000, 97:8910-8915.

87. Laporte J, Bedez F, Bolino A, Mandel J-L: Myotubularins, a large disease-associated family of cooperating catalytically active and inactive phosphoinositides phosphatases. Hum Mol Genet 2003, I 2(Spec No 2):R285-292

88. Tronchère $H$, Buj-Bello A, Mandel J-L, Payrastre B: Implication of phosphoinositide phosphatases in genetic diseases: the case of myotubularin. Cell Mol Life Sci 2003, 60:2084-2099.

89. Kim S-A, Taylor GS, Torgersen KM, Dixon JE: Myotubularin and MTMR2, phosphatidylinositol 3-phosphatases mutated in myotubular myopathy and type 4B Charcot-Marie-Tooth disease. J Biol Chem 2002, 277:4526-453I.

90. Schaletzky J, Dove SK, Short B, Lorenzo O, Clague MJ, Barr FA Phosphatidylinositol-5-phosphate activation and conserved substrate specificity of the myotubularin phosphatidylinositol 3-phosphatases. Curr Biol 2003, 13:504-509.

91. Berger P, Bonneick S, Willi S, Wymann M, Suter U: Loss of phosphatase activity in myotubularin-related protein 2 is associated with Charcot-Marie-Tooth disease type 4BI. Hum Mol Genet 2002, I I: 1569-1579.

92. Walker DM, Urbé S, Dove SK, Tenza D, Raposo G, Clague MJ: Characterization of MTMR3. an inositol lipid 3-phosphatase with novel substrate specificity. Curr Biol 200I, I I:1600-1605.

93. Maehama T, Dixon JE: The tumor suppressor, PTEN/MMACI, dephosphorylates the lipid second messenger, phosphatidylinositol 3,4,5-trisphosphate. J Biol Chem 1998, 273:| 3375-I 3378.

94. Caffrey JJ, Darden T, Wenk MR, Shears SB: Expanding coincident signaling by PTEN through its inositol 1,3,4,5,6-pentakisphosphate 3-phosphatase activity. FEBS Lett 200I, 499:6-10. 
95. Bansal VS, Caldwell KK, Majerus PW: The isolation and characterization of inositol polyphosphate 4-phosphatase. J Biol Chem 1990, 265:1806-1811.

96. Norris FA, Auethavekiat V, Majerus PW: The isolation and characterization of cDNA encoding human and rat brain inositol polyphosphate 4-phosphatase. J Biol Chem 1995, 270:16128-16133.

97. Norris FA, Atkins RC, Majerus PW: The cDNA cloning and characterization of inositol polyphosphate 4-phosphatase type II. Evidence for conserved alternative splicing in the 4-phosphatase family. J Biol Chem 1997, 272:23859-23864.

98. Ivetac I, Munday AD, Kisseleva MV, Zhang X-M, Luff S, Tiganis T, Whisstock JC, Rowe T, Majerus PW, Mitchell CA: The Type la inositol polyphosphate 4-phosphatase generates and terminates phosphoinositide 3-kinase signals on endosomes and the plasma membrane. Mol Biol Cell 2005, I 6:2218-2233.

99. Guo S, Stolz LE, Lemrow SM, York JD: SACI-like domains of yeast SACI, INP52, and INP53 and of human synaptojanin encode polyphosphoinositide phosphatases. I Biol Chem 1999, 274: $12990-12995$

100. Hughes WE, Woscholski R, Cooke FT, Patrick RS, Dove SK, McDonald NQ, Parker PJ: SACI encodes a regulated lipid phosphoinositide phosphatase, defects in which can be suppressed by the homologous Inp52p and Inp53p phosphatases. J Biol Chem 2000, 275:80I-808.

I0I. Nemoto Y, Kearns BG, Wenk MR, Chen H, Mori K, Alb JG Jr, De Camilli $P$, Bankaitis VA: Functional characterization of a mammalian Sacl and mutants exhibiting substrate-specific defects in phosphoinositide phosphatase activity. J Biol Chem 2000, 275:34293-343005.

102. Kisseleva MV, Wilson MP, Majerus PW: The isolation and characterization of a cDNA encoding phospholipid-specific inositol polyphosphate 5-phosphatase. J Biol Chem 2000 275:20110-20116

103. Schmid AC, Wise HM, Mitchell CA, Nussbaum R, Woscholski R Type II phosphoinositide 5-phosphatases have unique sensitivities towards fatty acid composition and head group phosphorylation. FEBS Lett 2004, 576:9-13.

104. Chi Y, Zhou B, Wang W-Q, Chung S-K, Kwon Y-U, Ahn Y-H, Chan Y-T, Tsujishita Y, Hurley JH, Zhang Z-Y: Comparative mechanistic and substrate specificity study of inositol polyphosphate 5-phosphatase Schizosaccharomyces pombe synaptojanin and SHIP2. I Biol Chem 2004, 279:44987-44995.

105. Chung J-K, Sekiya F, Kang H-S, Lee C, Han J-S, Kim SR, Bae YS, Morris AJ, Rhee SG: Synaptojanin inhibition of phospholipase $D$ activity by hydrolysis of phosphatidylinositol 4,5-bisphosphate. J Biol Chem 1997, 272: I 5980-I5985.

106. Rauh MJ, Sly LM, Kalesnikoff J, Hughes MR, Cao LP, Lam V, Krystal G: The role of SHIPI in macrophage programming and activation. Biochem Soc Trans 2004, 32:785-788.

107. Rameh LE, Tolias KF, Duckworth BC, Cantley LC: A new pathway for synthesis of phosphatidylinositol-4,5-bisphosphate. Nature 1997, 390:192-196.

108. Pawson T, Scott JD: Signaling through scaffold, anchoring, and adaptor proteins. Science 1997, 278:2075-2080.

109. Munday AD, Norris FA, Caldwell KK, Brown S, Majerus PW, Mitchell CA: The inositol polyphosphate 4-phosphatase forms a complex with phosphatidylinositol 3-kinase in human platelet cytosol. Proc Natl Acad Sci USA 1999, 96:3640-3645.

I I0. Gupta N, Scharenberg AM, Fruman DA, Cantley LC, Kinet J-P, Long EO: The SH2 domain-containing inositol 5'-phosphatase (SHIP) recruits the $\mathbf{p} 85$ subunit of phosphoinositide 3-kinase during FcyRIIbl-mediated inhibition of B cell receptor signaling. I Biol Chem 1999, 274:7489-7494.

III. Jackson SP, Schoenwaelder SM, Matzaris M, Brown S, Mitchell CA: Phosphatidylinositol 3,4,5-trisphosphate is a substrate for the $75 \mathrm{kDa}$ inositol polyphosphate 5-phosphatase and a novel 5-phosphatase which forms a complex with the p85/p I I0 form of phosphoinositide 3-kinase. EMBO J 1995, 14:4490-4500.

I 12. Kallunki T, Deng T, Hibi M, Karin M: c-Jun can recruit JNK to phosphorylate dimerization partners via specific docking interactions. Cell 1996, 87:929-939.

I 13. Hinchliffe KA, Giudici ML, Letcher AJ, Irvine RF: Type Il $\alpha$ phosphatidylinositol phosphate kinase associates with the plasma membrane via interaction with type I isoforms. Biochem 2002, 363:563-570.
I 4. Nandurkar HH, Layton M, Laporte J, Selan C, Corcoran L, Caldwell KK, Mochizuki Y, Majerus PW, Mitchell CA: Identification of myotubularin as the lipid phosphatase catalytic subunit associated with the 3-phosphatase adapter protein, 3-PAP. Proc Natl Acad Sci USA 2003, I00:8660-8665.

II5. Bondev A, Rubio I, Wetzker R: Differential regulation of lipid and protein kinase activities of phosphoinositides 3-kinase $\gamma$ in vitro. Biol Chem 380:1337-1340.

I 16. Cullen PJ, Hsuan J], Truong O, Letcher AJ, Jackson TR, Dawson AP, Irvine RF: Identification of a specific Ins $(1,3,4,5) P_{4}$-binding protein as a member of the GAPI family. Nature 1995, 376:527-530.

I 17. Robson JD, Davidson D, Veillette A: Inhibition of the Jun N-terminal protein kinase pathway by SHIP-I, a lipid phosphatase that interacts with the adaptor molecule Dok-3. Mol Cell Biol 2004, 24:2332-2343.

I I8. Boer A-K, Drayer AL, Vellenga E: Effects of overexpression of the SH2-containing inositol phosphatase SHIP on proliferation and apoptosis of erythroid AS-E2 cells. Leukemia 2001, I 5: 1750-1757.

I19. An H, Xu H, Zhang M, Zhou J, Feng T, Qian C, Qi R, Cao X: Src homology 2 domain-containing inositol-5-phosphatase I (SHIPI) negatively regulates TLR4-mediated LPS response primarily through a phosphatase activity- and PI-3K-independent mechanism. Blood 2005, I05:4685-4692.

120. Blero D, Zhang J, Pesesse X, Payrastre B, Dumont JE, Schurmans S, Erneux C: Phosphatidylinositol 3,4,5-trisphosphate modulation in SHIP2-deficient mouse embryonic fibroblasts. FEBS J 2005, 272:2512-2522.

12I. Tang X, Powelka AM, Soriano NA, Czech MP, Guilherme A: PTEN, but not SHIP2, suppresses insulin signaling through the phosphatidylinositol 3-kinase/Akt pathway in 3T3-LI adipocytes. J Biol Chem 2005, 280:22523-22529.

122. Weng L-P, Smith WM, Brown JL, Eng C: PTEN inhibits insulinstimulated MEK/MAPK activation and cell growth by blocking IRS-I phosphorylation and IRS-I/Grb-2/Sos complex formation in a breast cancer model. Hum Mol Genet 200I, 10:605-616.

123. Weng L-P, Brown JL, Baker KM, Ostrowski MC, Eng C: PTEN blocks insulin-mediated ETS-2 phosphorylation through MAP kinase, independently of the phosphoinositide 3-kinase pathway. Hum Mol Genet 2002, I I:1687-1696.

Publish with Bio Med Central and every scientist can read your work free of charge

"BioMed Central will be the most significant development for disseminating the results of biomedical research in our lifetime. "

Sir Paul Nurse, Cancer Research UK

Your research papers will be:

- available free of charge to the entire biomedical community

- peer reviewed and published immediately upon acceptance

- cited in PubMed and archived on PubMed Central

- yours - you keep the copyright 